\title{
PRODUÇÃO DE BIODIESEL: CONSIDERAÇÕES SOBRE AS DIFERENTES MATÉRIAS-PRIMAS E ROTAS TECNOLÓGICAS DE PROCESSOS
}

\author{
Andréia Boechat Delatorre \\ Doutoranda em Produção Vegetal/ Laboratório de Tecnologia de Alimentos/UENF/RJ \\ andreiadelatorre@hotmail.com \\ Priscila Maria Rodrigues \\ Mestranda em Produção Vegetal/Laboratório de Tecnologia de Alimentos/UENF/RJ \\ Cristiane de Jesus Aguiar \\ Mestranda em Produção Vegetal/Laboratório de Tecnologia de Alimentos/UENF/RJ \\ Vanessa Vicente Vieira Andrade \\ Aluna de Iniciação Científica/Laboratório de Tecnologia de Alimentos/UENF/RJ
}

\author{
Anália Arêdes \\ Aluna de Iniciação Científica/Laboratório de Entomologia e Fitopatologia/Laboratório de Tecnologia de \\ Alimentos/UENF/RJ
}

Victor Haber Perez

Pós-Doutorado em Engenharia de Alimentos/UNICAMP/SP

Laboratório de Tecnologia de Alimentos/UENF/RJ

\section{RESUMO}

O Biodiesel é um biocombustível derivado de fontes renováveis como óleos vegetais, gordura animal, óleos e gorduras residuais, que na presença de um catalisador, reagem com o álcool etílico ou metílico, resultando em um combustível de alta qualidade e grande potencial na substituição de óleo diesel. Essas reações podem ser realizadas tanto pela rota química (processo convencional) utilizando catalisadores químicos, ácidos ou básicos, quanto pela rota biológica (processo não convencional) com catalisadores biológicos, enzimas ou células imobilizadas. Neste processo químico, a glicerina é separada da gordura ou do óleo gerando dois produtos: uma mistura de ésteres alquílicos de ácidos graxos (biodiesel) e glicerina (resíduo da reação). No entanto, o biodiesel pode ser obtido por rota química ou enzimática, ou inclusive através de uma diversidade de processos que incluem, entre outros, microemulsões, pirólise, reações de esterificação e transesterificação. Sendo esta última alternativa a de maior adoção do ponto de vista tecnológico por apresentar eficaz conversão de triglicerídeos em ésteres metílicos ou etílicos em menor tempo de reação. Neste contexto, dada à diversidade de processos implementados atualmente e sendo o conhecimento da matéria prima de qualquer processo industrial um elemento essencial para definir rotas e alternativas tecnológicas eficientes, o presente trabalho discute algumas considerações sobre a produção de diferentes matérias-primas e rotas tecnológicas de processo.

Palavras-chave: Biodiesel, células imobilizadas, transesterificação, lipases. 


\begin{abstract}
Biodiesel is a biofuel that is derived from renewable sources such as vegetable oils, animal fats, waste oils and fats which, in the presence of a catalyzer, reacts with ethyl or methyl alcohol, resulting in a high quality fuel and with great potential to replace diesel fuel. These reactions may be caused by both a chemical route (conventional process) using chemical, acid or basic catalyzers and a biological route (non-conventional process) with biological catalyzers, enzymes or immobilized cells. In this chemical process, glycerin is separated from the fat or oil, producing two products: a mixture of fatty acid alkyl esters (biodiesel) and glycerin (residue of the reaction). However, biodiesel can be obtained by the chemical or enzymatic route, or even through a variety of processes that include, among others, microemulsions, pyrolysis, esterification and transesterification reactions. From a technological point of view, the latter is a widely adopted alternative for being efficient in converting triglycerides into methyl or ethyl esters and the reaction can be completed in a short time. In this context, given the diversity of processes implemented at present and the knowledge of raw materials in industrial processes being the key factor to determine routes and efficient technological alternatives, the present study presents some considerations on the production of different raw materials and the technological routes for processes.
\end{abstract}

Key words: Biodiesel, immobilized cells, transesterification, lipases.

\title{
1. INTRODUÇÃO
}

Quando se trata da matriz energética nacional e mundial, o petróleo é, sem dúvida, a principal matériaprima. Na década de 70 houve a crise do petróleo, afetando drasticamente a economia mundial. Com isso os países importadores de petróleo começaram a explorar suas reservas e investir em tecnologias de exploração na tentativa de evitar impactos como estes.

O petróleo, por ser um combustível de origem fóssil e, portanto lentamente formado pela natureza, levanta uma série de polêmicas em torno de sua escassez, visto que não é considerado uma fonte renovável de energia. Com isso sabemos que se mantivermos o atual ritmo de exploração ainda temos por alguns anos petróleo suficiente para nosso consumo. Porém, quando esta exploração atingir o seu máximo, um processo de declínio na produção será inevitável, e com isso a utilização de outros combustíveis se fará necessária.

Com base no exposto, cria-se a necessidade de se desenvolver fontes renováveis de energia para a gradual substituição dos combustíveis derivados do petróleo, pois além destes serem fontes esgotáveis apresentam um significativo impacto negativo na qualidade do meio ambiente, além de poluir o ar e causar mudanças climáticas, gera resíduos tóxicos.

O Brasil é um país de destaque na utilização de biomassa desde 1920, quando começou a utilizar o álcool como combustível. Desde então, vem ganhando destaque no que diz respeito à utilização dessa biomassa, tais como bagaço de cana-de-açúcar, madeira de reflorestamento, resíduos florestais e dejetos de animais.

Além disso, várias espécies de oleaginosas, tais como mamona, dendê (palma), girassol, babaçu, amendoim, pinhão manso e soja, dentre outras, possuem grande destaque na produção de biodiesel. Já que apresentamos alta produtividade de grãos que produzem óleos vegetais podendo ser utilizados para este fim. Outra matéria-prima potencial para produção de biodiesel no país consiste nos óleos e gorduras residuais, resultantes de processamento doméstico, comercial e industrial.

A reciclagem de resíduos agrícolas e agro-industriais vem ganhando espaço cada vez maior, não simplesmente por apresentarem matérias primas de baixo custo, mas, principalmente, porque os efeitos da 
degradação ambiental decorrente de atividades industriais e urbanas estão atingindo níveis cada vez mais alarmantes.

$\mathrm{O}$ biodiesel tem um grande potencial para o uso como alternativa de abastecimento em motores do ciclo diesel, pois é obtido de fontes renováveis, não são tóxicos e são biodegradáveis. Diversos estudos já demonstraram que o uso do biodiesel diminui a emissão de gases relacionados com o efeito estufa, tais como hidrocarbonetos, monóxido e dióxido de carbono, além de materiais particulados e óxidos de enxofre, esses últimos responsáveis pela chuva ácida (MA et al., 1999). Segundo LIMA (2004), quando comparado ao óleo diesel derivado de petróleo, o biodiesel pode reduzir em $78 \%$ as emissões de gás carbônico, considerando-se a reabsorção pelas plantas. Além disso, reduz em $90 \%$ as emissões de fumaça e praticamente elimina as emissões de óxido de enxofre. É importante frisar que o biodiesel pode ser usado em qualquer motor de ciclo diesel, com pouca ou nenhuma necessidade de adaptação.

A forma mais comum de obtenção deste biocombustível é por meio da reação dos óleos vegetais com metanol ou etanol, na presença de um catalizador, em processo químico ou biológico conhecido como transesterificação. Os produtos desta reação são as misturas de ésteres etílicos ou metílicos de ácidos graxos, que compõem o biodiesel, e glicerina, cujo maior constituinte é o glicerol.

\section{REVISÃO}

Há 30 anos, em 1973, iniciou-se a crise do petróleo. Os países, principalmente aqueles em desenvolvimento como o Brasil, foram afetados. Houve então a necessidade de se obter fontes de energia alternativas. No Brasil a saída para essa crise foi o Programa Nacional do Álcool (PROALCOOL), porém os veículos comerciais, como caminhões, ainda utilizam o diesel como combustível. A utilização de óleo vegetal ao invés de óleo diesel foi colocada em questão, pois estes óleos poluem menos e tem poder calorífico bastante elevado (LIMA, 2004).

As pesquisas sobre combustíveis alternativos e renováveis são realizadas desde a década de 20, porém a partir da década de 90 com a implantação de plantas industriais de produção em escala comercial começaram a ser impulsionadas, visando principalmente o meio ambiente e a procura de um novo combustível competitivo com o petróleo (PARAIZO, et al., 2005).

O governo brasileiro regularizou o biodiesel somente em 2004 quando promulgou a Medida Provisória 227, convertida na Lei 11.116 em 2005. O biodiesel já havia sido incluído na Medida Provisória 214 convertida na Lei 9478 em 1997. O biodiesel segundo esta Medida é "um combustível renovável e biodegradável, derivado de óleos vegetais e gorduras animais, que possa substituir parcialmente ou totalmente o óleo diesel de origem fóssil" (Secretaria da Receita Federal do Ministério da Fazenda, 2004). Já de acordo com a Lei 11.097 de 2005, que dispõe sobre a introdução do biodiesel na matriz energética brasileira, "combustível derivado de biomassa renovável para uso em motores a combustão interna ou, conforme regulamento para outro tipo de geração de energia, que possa substituir parcial ou totalmente combustíveis de origem fóssil". (BRASIL, 2005, art. $6^{\circ}$ )

A lei 11.097 fixou percentuais mínimos obrigatórios da adição de biodiesel ao óleo diesel comercializado aos consumidores finais, determinando que o percentual de adição mínimo deverá ser de 2,0\% (B2) de 2008 a 2012, para isso deveremos ser capazes de produzir aproximadamente 800 milhões de litros de biodiesel até o fim de 2012 podendo chegar a 2 bilhões até 2013 quando será obrigatório o uso do B5 (mistura de $5 \%$ de biodiesel), sendo o consumo atual de diesel no Brasil de 40 bilhões de litros (COSTA NETO, 2001).

O Ministério da Ciência e Tecnologia lançou em 2002 o Programa Brasileiro de Desenvolvimento Tecnológico do Biodiesel - PROBIODIESEL. Esse programa tem por objetivos desenvolver as tecnologias de produção e o mercado de consumo de biodiesel e estabelecer uma Rede Brasileira de Biodiesel, visando à redução das emissões de gases de efeito estufa.

Em julho de 2003, o Ministério de Minas e Energia - MME lançou o Programa Combustível Verde Biodiesel, tendo sido estabelecida uma meta de produção de 1,5 milhão de toneladas de biodiesel, destinado ao mercado interno e à exportação. O objetivo desse programa é diversificar a bolsa de combustíveis, diminuir a importação de diesel de petróleo e ainda criar emprego e renda no campo. 


\subsection{Matérias primas: aproveitamento de óleos e gorduras na produção de biodiesel}

As matérias-primas e os processos para a produção de biodiesel dependem da região considerada. As diversidades sociais, econômicas e ambientais geram distintas motivações regionais para a sua produção e consumo. O Brasil tem todas as condições para se tornar um grande produtor de biodiesel, possui grande potencial para produção de biomassa para fins energéticos. A mamona, o dendê, a soja, entre outras, podem ser abundantes fontes de energia e de inclusão social (LIMA, 2004), além dos óleos de frituras, provenientes do processamento de alimentos (KNOTHE, 2002).

Devido à grande extensão territorial e a seu clima favorável a plantação de sementes oleaginosas, o Brasil é um país que se destaca como um potencial produtor e explorador de biomassa para fins alimentícios, químicos e energéticos. No país, são cultivadas diversas espécies de oleaginosas (Tabela 1) que possuem potencial para serem utilizadas como matéria prima para a produção de biodiesel (OLIVEIRA et al., 2006).

Tabela 1 - Oleaginosas disponíveis no território nacional para a produção de biodiesel.

\begin{tabular}{|c|c|}
\hline$\underline{\text { Região }}$ & Óleos Vegetais disponíveis \\
\hline Norte & dendê, babaçu e soja \\
\hline Nordeste & $\begin{array}{c}\text { babaçu, soja, mamona, dendê, } \\
\text { algodão e coco }\end{array}$ \\
\hline Centro-Oeste & $\begin{array}{c}\text { soja, mamona, algodão, girassol, } \\
\text { dendê e gordura animal }\end{array}$ \\
\hline$\underline{\text { Sudeste }}$ & soja, mamona, algodão, girassol \\
\hline Sul & soja, milho, canola, girassol e algodão \\
\hline
\end{tabular}

Fonte: PARENTE, 2003.

A investigação de matérias-primas mais baratas representa uma estratégia associada à produção que tem sido utilizada para melhorar a viabilidade econômica do biodiesel. No entanto, a composição destas matérias primas pode exigir mudanças no processo e modificações das tecnologias já existentes para a produção de um biodiesel de boa qualidade. Além disso, a escolha da matéria-prima também depende largamente de fatores geográficos, climáticos e econômicos.

Quimicamente, óleos e gorduras (animal e vegetal) consistem de moléculas de triacilgliceróis (TG), as quais são constituídas de três moléculas de ácidos graxos (AG) de cadeia longa ligados na forma de ésteres a uma molécula de glicerol (Figura 1) (GERIS et al., 2007).

\subsection{1.Óleos Vegetais}

A busca por fontes de energias renováveis e de menor impacto ambiental vem ganhando espaço no mercado nacional e grande atenção nas pesquisas científicas, isso devido aos problemas de poluição oriundos do uso contínuo de combustíveis fósseis. Desse modo, surgem então os óleos vegetais que apresentam conteúdo energético similar ao do diesel (RAMOS et al., 2003; MEHER et al., 2006; MARCHETTI et al., 2005). Além disso, podem gerar biocombustíveis que contribuam com a redução dos níveis de poluição, principalmente nos grandes centros urbanos.

Alguns desses óleos são conhecidos como essenciais, e esta família de óleos vegetais não pode ser utilizada na produção de biodiesel, devido a sua constituição que apresenta misturas de terpenos, terpanos, 
fenóis, e outras substâncias aromáticas. No entanto, alguns óleos essenciais podem ser utilizados, in natura, na forma de mistura com óleo diesel mineral ou biodiesel. Podemos citar como exemplo desses óleos, o óleo de andiroba e o óleo da casca de laranja, entre outros (PARENTE, 2003).

Os óleos vegetais são produtos naturais constituídos essencialmente por ésteres de ácidos graxos e glicerina, e são conhecidos como triacilgliceróis, cujos ácidos graxos contêm cadeias de 8 a 24 átomos de carbono com diferentes graus de insaturação (SUARES, 2007). Óleos vegetais de espécies diferentes possuem composição dos ácidos graxos diferentes. Portanto, a análise da composição de ácidos graxos constitui o primeiro procedimento para a avaliação preliminar da qualidade do óleo bruto, isto pode ser obtido através de vários métodos analíticos tais como, a cromatografia líquida de alta eficiência, a cromatografia em fase gasosa e a espectroscopia de ressonância magnética nuclear de hidrogênio. A Tabela 2 apresenta a distribuição de ácidos graxos de alguns óleos e gorduras de diversas fontes.

Tabela 2 - Distribuição de ácidos graxos de alguns óleos e gorduras.

\begin{tabular}{|c|c|c|c|c|c|c|c|}
\hline \multirow[b]{2}{*}{$\begin{array}{l}\text { Tipo de Óleo ou } \\
\text { Gordura }\end{array}$} & \multicolumn{7}{|c|}{ Composição em ácidos graxos (\% em massa) } \\
\hline & $\begin{array}{l}\text { Láurico } \\
\mathrm{C}_{12} \mathrm{H}_{24} \mathrm{O}_{2}\end{array}$ & $\begin{array}{l}\text { Mirístico } \\
\mathrm{C}_{14} \mathrm{H}_{28} \mathrm{O}_{2}\end{array}$ & $\begin{array}{l}\text { Palmítico } \\
\mathrm{C}_{16} \mathrm{H}_{32} \mathrm{O}_{2}\end{array}$ & $\begin{array}{l}\text { Esteárico } \\
\mathrm{C}_{18} \mathrm{H}_{34} \mathrm{O}_{2}\end{array}$ & $\begin{array}{l}\text { Oléico } \\
\mathrm{C}_{18} \mathrm{H}_{32} \mathrm{O}_{2}\end{array}$ & $\begin{array}{l}\text { Linoléico } \\
\mathrm{C}_{18} \mathrm{H}_{30} \mathrm{O}_{2}\end{array}$ & $\begin{array}{l}\text { Linolênico } \\
\mathrm{C}_{18} \mathrm{H}_{28} \mathrm{O}_{2}\end{array}$ \\
\hline Algodão & - & 1,5 & 22 & 5 & 19 & 50 & - \\
\hline Amendoim & - & 0,5 & $\begin{array}{l}6,0- \\
11,4\end{array}$ & $3,0-6,0$ & $42,3-61$ & $13-33,5$ & - \\
\hline Babaçu & $44-45$ & $15-16,5$ & $5,8-8,5$ & $2,5-5,5$ & $12-16$ & $1,4-2,8$ & - \\
\hline Coco & $44-51$ & $13-18,5$ & $7,5-11$ & $1-3$ & $5-8,2$ & $1,0-2,6$ & - \\
\hline Dendê & - & $0,6-2,4$ & $32-45$ & $4,0-6,3$ & $38-53$ & $6-12$ & - \\
\hline Girassol & - & - & $3,6-6,5$ & $1,3-3$ & $14-43$ & $44-68$ & - \\
\hline Linhaça & - & - & 6 & 4 & $13-37$ & $5-23$ & $26-58$ \\
\hline Milho & - & - & 7 & 3 & 43 & 39 & - \\
\hline Oliva & - & 1,3 & $7-16$ & $1,4-3,3$ & $64-84$ & $4-15$ & - \\
\hline Soja & - & - & $2,3-11$ & $2,4-6$ & $23,5-31$ & $49-51,5$ & $2-10,5$ \\
\hline Sebo & - & $3-6$ & $25-37$ & $14-29$ & $26-50$ & $1-2,5$ & - \\
\hline
\end{tabular}

Fonte: RINALDI et al., 2007 
Ésteres alquílicos de ácidos graxos podem ser produzidos a partir de qualquer tipo de óleo vegetal, porém nem todos podem ser utilizados como matéria-prima para a produção de biodiesel. Isso devido a algumas de suas propriedades, tais como, alta viscosidade ou iodo, que são transferidos para o biocombustível, que os tornam inadequados para uso direto em motores do ciclo diesel (SUAREZ, 2002; SOARES, 2004). Por outro lado os óleos vegetais apresentam várias vantagens para uso como combustível, visto seu elevado poder calorífico, ausência de enxofre em suas composições e são de origem renováveis. (KNOTHE, 2005). Com isso vários estudos estão sendo realizados para desenvolver derivados desses óleos, cujas propriedades e desempenho se aproximam do óleo diesel de origem fóssil, isso porque um combustível alternativo deve ter uma técnica praticável, ser economicamente competitivo, ambientalmente aceitável e prontamente disponível (GERPEN, 2005; KNOTHE, 2005 e MEHER, 2006).

\subsection{2. Óleos de frituras}

Além dos óleos e gorduras virgens, os óleos e gorduras residuais também constituem matéria-prima para a produção de biodiesel. Algumas possíveis fontes desses óleos e gorduras são: lanchonetes e cozinhas industriais, indústrias onde ocorre a fritura de produtos alimentícios, esgotos municipais onde a nata sobrenadante é rica em matéria graxa e águas residuais de processos de indústrias alimentícias (SILVA et al., 2005).

A fritura por imersão é um processo que utiliza óleos e gorduras vegetais como meio de transferência de calor, e é amplamente utilizado na produção de alimentos. Este processo gera um volume significativo de óleos e gorduras cuja disposição final não tem um destino adequado (COSTA et al., 2000). Com isso alguns trabalhos têm sido realizados com o objetivo de aproveitar os resíduos gerados na indústria alimentícia e evitar o encaminhamento destes à aterros sanitários, minimizando o impacto ambiental do acúmulo destes resíduos. Outro problema existente na fritura de alimentos está relacionada com o tempo de utilização desses óleos que variam de um estabelecimento para o outro, principalmente pela falta de legislação que determine a troca do óleo usado. Por essa razão, é difícil fazer um levantamento preciso da disponibilidade desse resíduo em grandes centros urbanos (COSTA et al., 2000).

A oxidação é um processo acelerado pela alta temperatura e é a principal responsável pela modificação das características físico-químicas e organolépticas do óleo. Com o aquecimento elevado o óleo fíca viscoso, escuro, com maior índice de acidez, além de desenvolver um odor desagradável (COSTA et al., 2000). Sendo assim, segundo TURATTI et al., (2002), essa deterioração oxidativa provoca a formação de subprodutos com sabor e odor fortes e desagradáveis. Com isso, o óleo de fritura apresenta muitas impurezas e para minimizar este problema, é realizado um processo de pré-purificação e de secagem antes da reação de transesterificação. Por outro lado, mesmo com a purificação desses óleos, este processo ainda é considerado inviável sob o ponto de vista econômico (COSTA et al., 2000).

LEE et al., (2002) desenvolveram, estudos sobre a produção de biodiesel a partir de gordura animal e gorduras resultantes dos processos de fritura. A gordura animal foi fracionada para a separação dos ácidos graxos saturados, que resultam em ésteres metílicos sujeitos a problemas de desempenho, a baixas temperaturas. Em seguida a gordura fracionada foi submetida a transesterificação com catálise enzimática, utilizando-se etanol e metanol, separadamente. Para a conversão dos resíduos de restaurantes, estes pesquisadores utilizaram reação de transesterificação com catálise alcalina. Porém, a presença de compostos polares como água e ácidos graxos livres retardam a reação e diminuem o seu rendimento, e por este motivo, estes compostos foram removidos.

A utilização de resíduos gordurosos para a obtenção de biodiesel representa uma alternativa ambiental adequada, uma vez que é dada uma melhor destinação final para os mesmos. A reciclagem dos óleos residuais como biodiesel é muito vantajosa, já que esses resíduos são matérias-prima baratas, podendo ser coletadas em restaurantes, indústrias, lanchonetes e residências, evitando assim grande contaminação do meio ambiente.

Segundo, MITTELBACH e TRITTHART, a utilização de biodiesel de óleos de fritura em motores do ciclo diesel apresentou resultados satisfatórios. A Tabela 3 compara a composição do biodiesel de óleo de fritura com óleo diesel. 
Tabela 3 - Especificações do óleo diesel e do biodiesel de óleo de fritura.

\begin{tabular}{lcc}
\hline Características & Óleo diesel* & Biodiesel \\
\hline Densidade $15^{\circ} \mathrm{C}\left(\mathrm{kg} / \mathrm{m}^{3}\right)$ & 0,849 & 0,88 \\
Ponto inicial de destilação $\left({ }^{\circ} \mathrm{C}\right)$ & 189 & 307 \\
$10 \%$ & 220 & 319 \\
$20 \%$ & 23 & 328 \\
$50 \%$ & 263 & 333 \\
$70 \%$ & 286 & 335 \\
$80 \%$ & 299 & 337 \\
$90 \%$ & 317 & 340 \\
Ponto final de destilação $\left({ }^{\circ} \mathrm{C}\right)$ & 349 & 342 \\
Aromáticos $(\%, \mathrm{v} / \mathrm{v})$ & 31,5 & - \\
Carbono $(\%)$ & 86,0 & 77,4 \\
Hidrogênio $(\%)$ & 13,4 & 12,0 \\
Oxigênio (\%) & 0,0 & 11,2 \\
Enxofre (\%) & 0,3 & 0,03 \\
Índice de cetano & 46,1 & 44,6 \\
Número de cetano & 46,2 & 50,8 \\
Valor calórico (MJ/kg) & 42,30 & 37,50 \\
\hline
\end{tabular}

* Óleo diesel com especificação para combustíveis do tipo US-2D.

Fonte: MITTELBACH et al., 1988

Alguns fatores como o clima, geografia e economia de uma região determinam o óleo vegetal de maior interesse para uso potencial nos biocombustíveis. Nos Estados Unidos, por exemplo, o óleo de soja é considerado como matéria-prima primordial e, nos países tropicais, é o óleo de palma. Na Alemanha, o óleo de colza é utilizado na produção de biodiesel, sendo distribuído de forma pura, isento de qualquer mistura ou aditivação. Há também a produção de biodiesel na Malásia a partir do óleo de palma. Os óleos vegetais mais comuns, cuja matéria prima é abundante no Brasil, são soja, milho, amendoim, algodão, babaçu e palma (FERRARI, 2005). Existem dois processos que são muito usados para conversão desses óleos em combustível são eles a transesterificação, e o craqueamento (LIMA, 2004).

A transesterificação é o processo mais utilizado atualmente e consiste numa reação química dos óleos vegetais ou gorduras animais com álcool comum, etanol ou metanol, para produzir um éster e um co-produto, o glicerol. Este processo tem por objetivo modificar a estrutura molecular de óleos vegetais tornando-o praticamente idêntico a do óleo diesel e consequentemente com propriedades físico-química iguais (CONCEIÇÃO et al., 2005). Já o craqueamento ou pirólise é um processo de quebra das cadeias de moléculas de carbono em alta temperatura e na ausência de oxigênio, onde as reações são induzidas por energia térmica. Este processo é realizado sob vácuo ou atmosfera de gás inerte, como hélio ou nitrogênio, e formando uma mistura de compostos químicos com propriedades muito semelhantes às do diesel de petróleo (FIELD'S et al., 2008). 


\subsection{Reação de transesterificação}

Os ácidos graxos são encontrados, em óleos e gorduras, de forma não associada, sendo assim conhecidos como ácidos graxos livres, ou na forma associada formando outras classes de compostos químicos como os fosfatídeos. Por outro lado uma das principais formas de encontrarmos ésteres de ácidos graxos na natureza é através dos glicerídeos, também conhecidos como triacilglicerídeos, os quais são formados pela condensação entre ácidos graxos e tri álcool, estes compostos são classificados de acordo com o número de moléculas de ácidos graxos que se associam ao glicerol. É importante salientar que os triacilglicerídeos podem ser formados por ácidos graxos iguais ou diferentes entre si. Existem diversos tipos de ácidos graxos de ocorrência natural, sendo os mais importantes listados na Tabela 4 (COSTA NETO, 2001).

Tabela 4 - Principais ácidos graxos encontrados na natureza.

\begin{tabular}{|c|c|c|c|}
\hline Ácido graxo & Nome Sintético & Símbolo & Fórmula \\
\hline Butírico & Butanóico & $\mathrm{C}_{4}$ ou $\mathrm{C}_{4: 0}$ & $\mathrm{C}_{4} \mathrm{H}_{8} \mathrm{O}_{2}$ \\
\hline Capróico & Hexanóico & $\mathrm{C}_{6}$ ou $\mathrm{C}_{6: 0}$ & $\mathrm{C}_{4} \mathrm{H}_{12} \mathrm{O}_{2}$ \\
\hline Caprílico & Octanóico & $\mathrm{C}_{8}$ ou $\mathrm{C}_{8: 0}$ & $\mathrm{C}_{8} \mathrm{H}_{16} \mathrm{O}_{2}$ \\
\hline Cáprico & Decanóico & $\mathrm{C}_{10}$ ou $\mathrm{C}_{10: 0}$ & $\mathrm{C}_{10} \mathrm{H}_{20} \mathrm{O}_{2}$ \\
\hline Otusílico & cis-4-decenóico & $\mathrm{C}_{10: 1(\mathrm{n} 4)}$ & $\mathrm{C}_{10} \mathrm{H}_{18} \mathrm{O}_{2}$ \\
\hline Caproleico & cis-9-decenóico & $\mathrm{C}_{10: 2(\mathrm{n} 9)}$ & $\mathrm{C}_{10} \mathrm{H}_{18} \mathrm{O}_{2}$ \\
\hline Láurico & Dodecanóico & $\mathrm{C}_{12}$ ou $\mathrm{C}_{12: 0}$ & $\mathrm{C}_{12} \mathrm{H}_{24} \mathrm{O}_{2}$ \\
\hline Lauroleico & cis-5-lauroleico & $\mathrm{C}_{12: 1(\mathrm{n} 5)}$ & $\mathrm{C}_{12} \mathrm{H}_{22} \mathrm{O}_{2}$ \\
\hline Lindérico & cis-4-dodecenóico & $\mathrm{C}_{12: 1(\mathrm{n} 4)}$ & $\mathrm{C}_{12} \mathrm{H}_{22} \mathrm{O}_{2}$ \\
\hline Mirístico & Tetradecanóico & $\mathrm{C}_{14}$ ou $\mathrm{C}_{14: 0}$ & $\mathrm{C}_{14} \mathrm{H}_{28} \mathrm{O}_{2}$ \\
\hline Miristoleico & cis-9- tetradecenóico & $\mathrm{C}_{14: 1(\mathrm{n} 9)}$ & $\mathrm{C}_{14} \mathrm{H}_{26} \mathrm{O}_{2}$ \\
\hline Tsuzuico & cis-4- tetradecenóico & $\mathrm{C}_{14: 1(\mathrm{n} 4)}$ & $\mathrm{C}_{14} \mathrm{H}_{26} \mathrm{O}_{2}$ \\
\hline Palmítico & Hexadecanóico & $\mathrm{C}_{16}$ ou $\mathrm{C}_{16: 0}$ & $\mathrm{C}_{16} \mathrm{H}_{32} \mathrm{O}_{2}$ \\
\hline Palmitoleico & cis-9- hexadecenóico & $\mathrm{C}_{16: 1(\mathrm{n} 9)}$ & $\mathrm{C}_{16} \mathrm{H}_{30} \mathrm{O}_{2}$ \\
\hline Esteárico & Octadecanóico & $\mathrm{C}_{18}$ ou $\mathrm{C}_{18: 0}$ & $\mathrm{C}_{18} \mathrm{H}_{36} \mathrm{O}_{2}$ \\
\hline Petroselínico & cis-6-octadecenóico & $\mathrm{C}_{18: 1(\mathrm{n} 6)}$ & $\mathrm{C}_{18} \mathrm{H}_{34} \mathrm{O}_{2}$ \\
\hline Oleico & cis-9-octadecenóico & $\mathrm{C}_{18: 1(\mathrm{n} 9)}$ & $\mathrm{C}_{18} \mathrm{H}_{34} \mathrm{O}_{2}$ \\
\hline Eládico & trans-9-octadecenóico & $\mathrm{C}_{18: 1(\operatorname{tn} 9)}$ & $\mathrm{C}_{18} \mathrm{H}_{34} \mathrm{O}_{2}$ \\
\hline
\end{tabular}




\begin{tabular}{|l|l|c|c|}
\hline Vaccênico & cis-11-octadecenóico & $\mathrm{C}_{18: 1(\mathrm{n} 11)}$ & $\mathrm{C}_{18} \mathrm{H}_{34} \mathrm{O}_{2}$ \\
\hline Linoleico & cis-9,cis-12-octadecadienóico & $\mathrm{C}_{18:(\mathrm{n} 9,12)}$ & $\mathrm{C}_{18} \mathrm{H}_{32} \mathrm{O}_{2}$ \\
\hline Linolênico & cis-9,cis-12, cis-15-octadecatrienóico & $\mathrm{C}_{18: 3(\mathrm{n} 9,12,15)}$ & $\mathrm{C}_{18} \mathrm{H}_{30} \mathrm{O}_{2}$ \\
\hline Ricinoleico & 12-hidrox- cis-9-octadecenóico & $\mathrm{C}_{18: 1(\mathrm{n} 9)}: \mathrm{OH}_{(\mathrm{n} 12)}$ & $\mathrm{C}_{18} \mathrm{H}_{34} \mathrm{O}_{2}$ \\
\hline Araquídico & Eicosanóico & $\mathrm{C}_{20}$ ou $\mathrm{C}_{20: 0}$ & $\mathrm{C}_{20} \mathrm{H}_{40} \mathrm{O}_{2}$ \\
\hline Gadoleico & cis-9-eicosenóico & $\mathrm{C}_{20: 1(\mathrm{n} 9)}$ & $\mathrm{C}_{20} \mathrm{H}_{38} \mathrm{O}_{2}$ \\
\hline Gadóico & cis-11-eicosenóico & $\mathrm{C}_{20: 1(11)}$ & $\mathrm{C}_{20} \mathrm{H}_{38} \mathrm{O}_{2}$ \\
\hline Behênico & Docosanóico & $\mathrm{C}_{22}$ ouC $\mathrm{C}_{22: 0}$ & $\mathrm{C}_{22} \mathrm{H}_{44} \mathrm{O}_{2}$ \\
\hline Cetoleico & cis-11-Docosenóico & $\mathrm{C}_{22: 1(\mathrm{n} 11)}$ & $\mathrm{C}_{22} \mathrm{H}_{42} \mathrm{O}_{2}$ \\
\hline Erúcico & cis-13-Docosenóico & $\mathrm{C}_{22: 1(\mathrm{n} 13)}$ & $\mathrm{C}_{22} \mathrm{H}_{42} \mathrm{O}_{2}$ \\
\hline Lignocérico & Tetracosanóico & $\mathrm{C}_{24}$ ou $\mathrm{C}_{24: 0}$ & $\mathrm{C}_{24} \mathrm{H}_{46} \mathrm{O}_{2}$ \\
\hline Nervônico & cis-15-tetracosenóico & $\mathrm{C}_{24: 1(\mathrm{n} 15)}$ & $\mathrm{C}_{24} \mathrm{H}_{46} \mathrm{O}_{2}$ \\
\hline
\end{tabular}

Nos últimos anos, a evolução da tecnologia mostra uma tendência à adoção da transesterificação para produzir um éster e um co-produto, o glicerol. Entretanto algum excesso de álcool é necessário para aumentar o rendimento da produção dos ésteres alquílicos. Assim, os triésteres de ácidos graxos que compõe os óleos vegetais são transformados em monoésteres (VAN GERPEN e KNOTHE, 2005). Além de permitir a posterior separação dos ésteres do glicerol. (DORADO et al., 2004). O processo de transesterificação de óleos vegetais e gorduras é uma seqüência de três reações reversíveis e consecutivas em que os mono e os diacilgliceróis são os intermediários, como mostra a Figura 1.

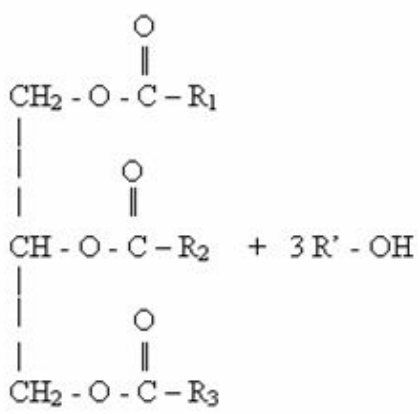

TRIGLICERÍDEO ÁLCOOL<smiles>[R]OC([R1])=O</smiles><smiles>[R]OC([R])O[R]</smiles>

ESTERES
GLICERINA

Figura 1 - Reação de Transesterificação. R1, R2, e R3 são cadeias longas de hidrocarboneto e R' é uma cadeia de hidrocarboneto de um álcool simples como o etanol ou metanol. Fonte: MELO et al., 2007. 
A transesterificação de óleos vegetais e gordura animal pode ser conduzida por uma variedade de rotas tecnológicas em que se pode empregar catalisadores alcalinos, ácidos ou enzimáticos sendo que a matéria prima é de fundamental importância na decisão da catálise. (RAMOS et al., 2003; GERPEN e KNOTHE, 2005)

O emprego da catálise ácida (Figura 2), na qual o ácido sulfúrico é o mais empregado, apresenta uma cinética muito lenta de reação quando comparada ao uso de catalisadores básicos. Outra desvantagem do uso desse catalisador esta associado à necessidade de sua remoção após a transesterificação, visando prevenir possíveis danos às partes integrantes dos motores (CANAKSI e GERPEN, 2001).

Na primeira etapa ocorre a protonação do grupo carbonílico do éster (Etapa 1), formando um carbocátion que, após o ataque nucleofílico do álcool resulta na formação de um intermediário tetraédrico (Etapa 2). Este intermediário elimina o diacilglicerol para formar o éster metílico e regenerar o catalisador ácido (Etapa 3). Esta reação se estende para os di e monoacilgliceróis (MILINSK, 2007).<smiles>[R]C(O)=CC[Pb]=C</smiles><smiles></smiles><smiles>[R]OO</smiles>

\section{Etapa 1}<smiles></smiles><smiles>[R]C(O)(O[2H])O[Hg]</smiles>

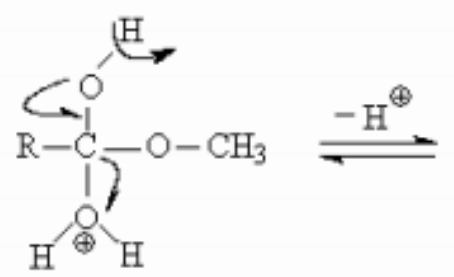<smiles>[R]C(=O)OC</smiles>

$+$

$$
\mathrm{H}-\mathrm{O}-\mathrm{H}
$$

Etapa 3

Figura 2 - Mecanismo de reação de esterificação de um ácido graxo com metanol na presença de catalisador ácido. Fonte: MILINSK, 2007.

A catálise básica por sua vez é muito rápida, e leva a excelentes rendimentos, na maioria das vezes superior a 90\%. Contudo seu emprego apresenta como inconveniente a grande sensibilidade à presença de água e ácidos graxos livres, que mesmo em teores reduzidos afetam o rendimento da reação e leva a formação de gel e sabão (saponificação), além de comprometer a qualidade do produto final (VAN GERPEN e KNOTHE, 2005; HE et al., 2008). As reações envolvidas neste processo estão apresentadas na Figura 3.

A primeira etapa ocorre pela reação entre a base $(\mathrm{NaOH})$ e o metanol produzindo alcóxido e água (Etapa 1). O ataque nucleofílico do íon alcóxido se dá no carbono carbonílico defíciente em elétrons da molécula do triacilglicerol, resultando na formação de um intermediário tetraédrico. O rompimento da ligação entre carbono e oxigênio deste intermediário leva ao produto, éster metílico (Etapa 2) e ao diacilglicerol formado após a remoção do átomo de hidrogênio do metanol (Etapa 3), para formar o íon metóxido e permitir a continuidade do processo. Por outro lado, a etapa 1 da reação esquematizada na Figura 3 mostra a formação de água no meio reacional quando se utiliza hidróxidos. A presença de água pode promover a hidrólise de ésteres formados 
levando a produção de sabão, pelo ataque do íon hidróxido, (Figura 4), diminuindo o rendimento da reação de transesterificação, pois esta reação é irreversível (SOLOMONS e FRYHLE, 2002).

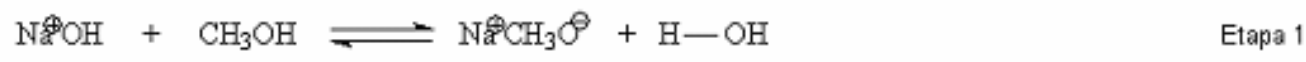
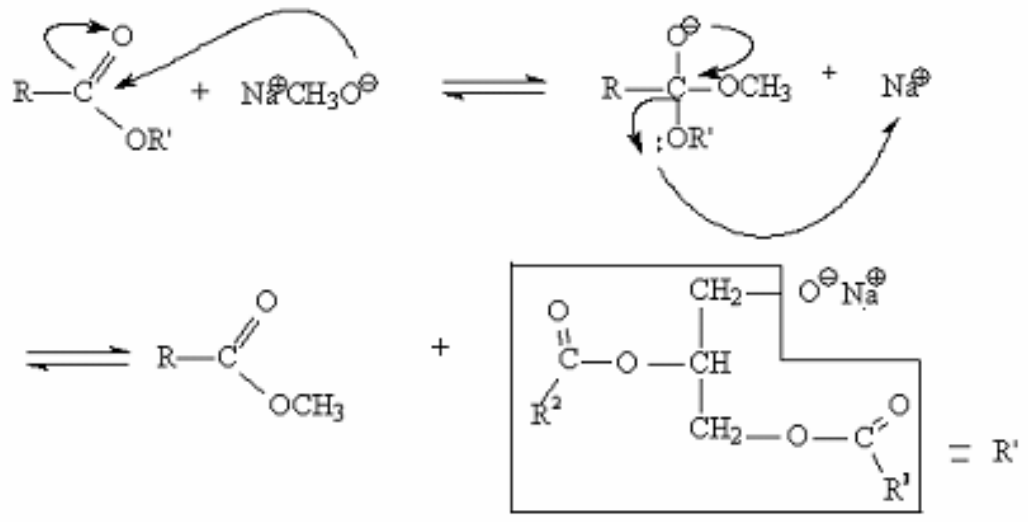

Etapa 2

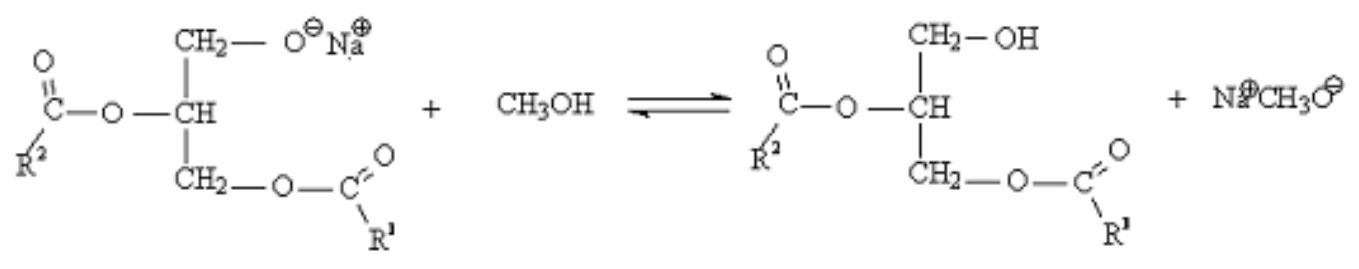

Etapa 3

Figura 3 - Mecanismo de reação de transesterificação de um triacilglicerol com metanol na presença de hidróxido de sódio. Fonte: MILINSK, 2007.

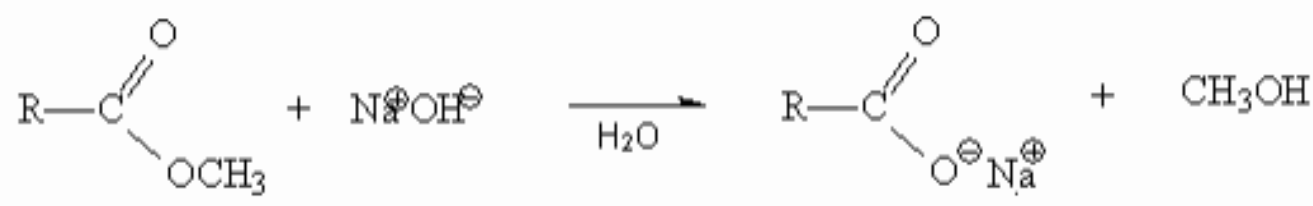

Figura 4 - Reação de hidrólise: saponificação. Fonte: MILINSK, 2007.

Os catalisadores enzimáticos oferecem vantagens e desvantagens (Tabela 5) frente aos catalisadores ácidos e básicos, como a menor sensibilidade à presença de água (não formam sabões), recuperação do catalisador, separação do biodiesel. Além de serem uma opção mais atrativa ambientalmente. No entanto, diversos estudos apontam que a enzima imobilizada em um suporte adequado é sempre mais ativa que a livre em condições reacionais comparáveis. Isto devido a maior eficácia do sistema heterogêneo devido a maior disponibilidade dos sítios ativos das enzimas quando confinadas nos poros do sólido, uma vez que em sistema homogêneo ocorre a formação de agregados, ficando os sítios não disponíveis no interior dos mesmos (De CASTRO et al., 2004, HA et al., 2007). Além disso, é uma alternativa que reduz o impacto ambiental pela minimização dos resíduos gerados no processo. No entanto seu elevado custo e as dificuldades referentes ao controle do processo têm reduzido seu uso (VILLENEUVE et al., 2000; WANG et al., 2008). A transesterificação utilizando catalizadores enzimáticos vem sendo estudada no país testando lipases imobilizadas 
disponíveis comercialmente, assim como solúveis previamente imobilizadas em suportes (NASCIMENTO et al., 2001; COSTA NETO, 2001).

Tabela 5 - Principais vantagens e desvantagens dos processos químico e enzimático para a produção de biodiesel.

\begin{tabular}{|c|c|c|}
\hline Processo & Vantagens & Desvantagens \\
\hline \multirow{4}{*}{ Químico } & Simplicidade & $\begin{array}{l}\text { Dificuldade de separação do } \\
\text { catalisador }\end{array}$ \\
\hline & $\begin{array}{l}\text { Alto rendimento } \\
\text { Curto tempo de } \\
\text { reação }\end{array}$ & $\begin{array}{l}\text { Impossibilidade de } \\
\text { reutilização } \\
\text { do catalisador }\end{array}$ \\
\hline & & $\begin{array}{l}\text { Dificuldade de utilização de } \\
\text { etanol hidratado }\end{array}$ \\
\hline & & $\begin{array}{l}\text { Obtenção de produtos com } \\
\text { menor grau de pureza }\end{array}$ \\
\hline \multirow{3}{*}{ Enzimático } & $\begin{array}{l}\text { Facilidade de separação } \\
\text { do catalisador (suporte) }\end{array}$ & \\
\hline & $\begin{array}{l}\text { Obtenção de produtos } \\
\text { com maior grau de } \\
\text { pureza }\end{array}$ & $\begin{array}{l}\text { Custo das enzimas } \\
\text { Baixo rendimento }\end{array}$ \\
\hline & $\begin{array}{l}\text { Possibilidade de utilizar } \\
\text { etanol hidratado na } \\
\text { reação }\end{array}$ & \\
\hline
\end{tabular}

O uso de lipases proporciona inúmeras vantagens como à diminuição de gastos com energia e a minimização da degradação térmica dos compostos, quando comparados às vias químicas tradicionais. Estas são provavelmente as principais atrações que levam à substituição das tecnologias químicas atuais pelas biológicas (HASAN et al.,2006, ROYON et al., 2007).

\subsection{Lipases}

As lipases (triglicerol acil-hidrolases, EC 3.1.1.3) são classificadas como hidrolases e atuam sobre ligações éster presentes em acilgliceróis, liberando ácidos graxos e glicerol, constituindo uma classe especial de esterases (COVIZZI et al., 2007).

As lipases são encontradas em tecidos de vários animais e plantas, e podem ser produzidas por fermentação usando várias espécies de microrganismos, tais com os fungos Aspergillus mucor, Rhizopus penicillium, Geotrichum sp., por leveduras de Tulopis sp. e Cândida sp. e bactérias como Pseudomonas sp., Achromobacter sp. e Staphylococcus sp. Do ponto de vista econômico e industrial, as lipases produzidas por microrganismos são preferíveis a aquelas de fontes animais e vegetais, devido ao alto custo do seu isolamento (JAEGER et al., 2002).

As lipases são muito utilizadas em síntese orgânica devido à sua grande disponibilidade, baixo custo e não requerem co-fatores, atuam em uma faixa de $\mathrm{pH}$ relativamente grande, são muito estáveis neste meio que apresentam variação de $\mathrm{pH}$, especificidade, regiosseletividade, quimioseletividade e enantioseletividade. 
Possuem a habilidade de catalisar reações de esterificações, transesterificações (acidólise, interesterificação, alcoólise), aminólise e tiotransesterificação em solvente orgânico anidro e sistema bifásico. As lipases têm sido extensivamente investigadas com relação às suas propriedades bioquímicas, mais recentemente, para aplicações industriais (DALLA-VECCHIA et al., 2004).

Nos últimos anos, com o intuito de aumentar a atividade catalítica de lipases, foram apresentados na literatura vários procedimentos de imobilização ou modificações na sua estrutura nativa, sendo que estes processos envolvem diferentes graus de complexidade e eficiência. Os métodos de imobilização requerem uma interação fraca ou a formação de ligações covalentes entre a lipase e o suporte (TISCHER e KASCHE, 1999; DALLA-VECCHIA et al., 2004).

\subsection{Biocatalisador imobilizado}

O estado morfológico do microrganismo durante o processo fermentativo influencia diretamente a obtenção dos produtos microbianos de interesse, por diminuir o tempo de cultivo e aumentar o rendimento do processo (FENG et al., 2003). Os fungos, por exemplo, apresentam uma morfologia bastante complexa com estruturas celulares diferentes em cada etapa do seu ciclo de vida (PRASAD et al., 2005).

Uma das alternativas encontradas para "engenheirar" a estrutura morfológica destes microrganismos é a imobilização celular, de maneira que seja preservada a atividade catalítica desejada, para aplicação tanto em escala de laboratório quanto industrial. Esta tecnologia se restringe à produção de metabólitos extracelulares ou a utilização de microrganismos como biocatalizadores (KOURKOUTAS et al., 2004; PRASAD et al., 2005).

A imobilização celular consiste no confinamento físico das células em uma região definida de espaço, na qual são mantidas suas atividades catalíticas em processos de operação contínua ou descontínua possibilitando a reutilização das mesmas. A maioria dos processos fermentativos industriais convencionais utiliza células livres em suspensão, porém o uso de microrganismos imobilizados permite um aumento da produtividade devido à elevada concentração de células. (FREEMAN; LILLY, 1998).

A maior concentração de células microbianas no suporte garante a síntese dos metabólitos e aumenta a eficiência da fermentação. Além disso, facilita a recuperação dos produtos de interesse do metabolismo na fase de "downstream" e ajuda na manutenção dos fermentadores, uma vez que não apresenta problemas de adesão e obstrução aos eletrodos e tubos (MOREIRA et al., 1998; KOURKOUTAS et al., 2004; BERGMAIER; CHAMPAGNE; LACROIX, 2005).

A imobilização celular surgiu como alternativa à imobilização de enzimas, pois não requer etapas de extração, isolamento e purificação. Desde então, o processo de imobilização tem conseguido vários avanços, principalmente na área da biotecnologia, permitindo a obtenção de metabólitos microbianos de maneira mais eficiente. As técnicas podem ser classificadas em: a) naturais, as quais incluem a formação de biofilmes e a adesão/adsorção microbiana em suportes sintéticos ou naturais, e b) artificiais, as quais incluem o envolvimento em matrizes como alginato de cálcio ou uso de agentes ligantes (ligação covalente) (COVIZZI et al., 2007).

A imobilização natural ocorre espontaneamente por meio de interações eletrostáticas. Já no caso da imobilização artificial, as células são ligadas às matrizes por ligações covalentes, utilizando-se agentes ligantes como glutaraldeído ou carbodiimida. A célula permanece viável independente dos possíveis danos causados pelo procedimento. A Figura 4 ilustra os diferentes tipos de imobilização celular utilizadas em pesquisas e em plantas industriais (COVIZZI et al., 2007).

A eficiência do suporte do processo pode ser avaliada pela capacidade da matriz em alojar a maior quantidade de células viáveis possível, sem limitar a transferência de massa entre o microrganismo e o meio de cultivo. Diferentes métodos de imobilização celular (Figura 5) têm sido utilizados na obtenção de sistemas eficientes para utilização nos processos fermentativos em reatores industriais, tornando-os economicamente viáveis e apresentando melhor produtividade. Porém, a escolha de uma matriz adequada para a imobilização das células é de fundamental importância para a obtenção do produto desejado, sendo esta escolha peculiar para cada microrganismo e metabólito estudado (PETRE et al., 1999). O tamanho do poro, a porosidade e o grau de hidrofobicidade da matriz interferem na intensidade da adesão celular (SILVA et al., 2006). 


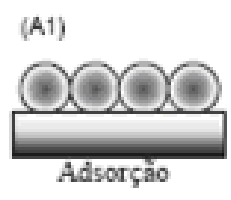

(B)

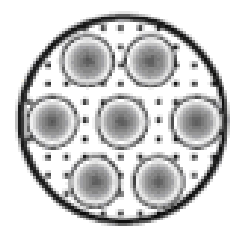

Engaiolamebto em matriz porosa

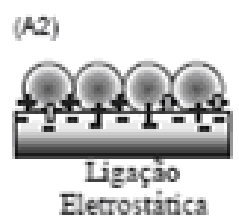

(C1)

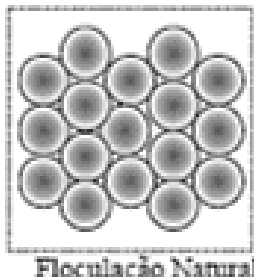

(Auto agrezaçào)
(A3)

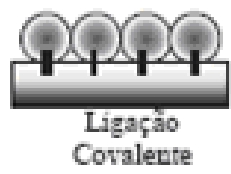

(c2)



Foculação Artificial

(Liz̨ą̧ảo cruzada)

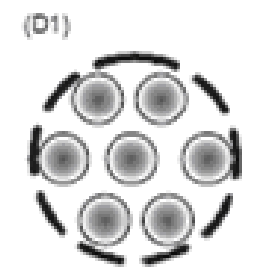

Microencapsulaçào

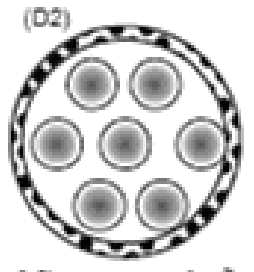

Microencapsulaçào
(D3)

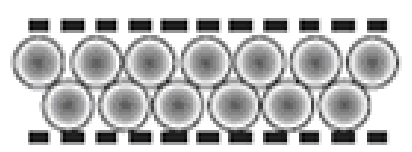

Coutencio entre Micromembranss

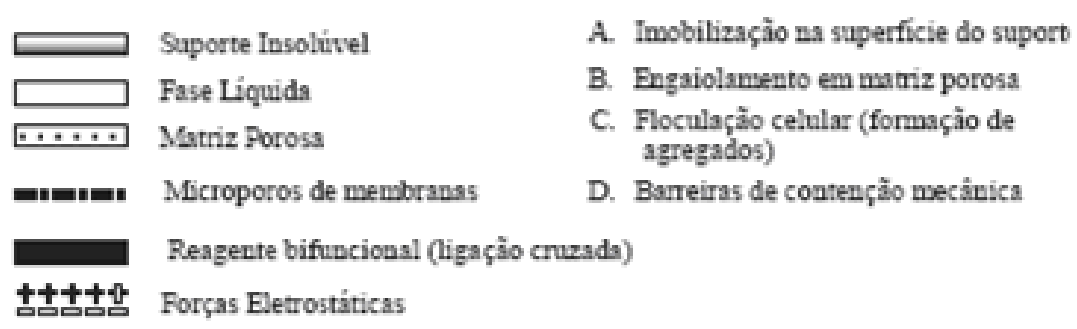

Figura 5 - Diferentes métodos de imobilização celular de microorganismos (Fonte: PILKINGTON et al. 1998).

\subsubsection{Imobilização de células microbianas por adsorção}

As primeiras pesquisas acerca de imobilização de células microbianas surgiram a partir das observações da habilidade de alguns microrganismos se fixarem naturalmente em superfícies de diferentes ambientes, desde caules de árvores, como no caso de microrganismos fitopatogênicos, até cateteres hospitalares, em se tratando de bactérias oportunistas. A colonização da superfície por formação de biofilmes é uma estratégia universal das bactérias para a sobrevivência e pode ocorrer naturalmente, como no caso das bactérias formadoras da cárie, ou até mesmo em instalações industriais (JUNTER; JOUENNE, 2004).

Os fungos filamentosos são microrganismos eucarióticos amplamente aplicados em processos fermentativos em indústrias, visando principalmente à produção de enzimas de interesse comercial (WANG et al., 2005). Para a imobilização celular destes fungos, utilizam-se suportes porosos visto que ocorre adesão das células microbianas à superfície do suporte. Quando os poros são maiores, as células em crescimento (hifas) penetram no suporte, preenchendo seu espaço interno. Este método de imobilização também se utiliza da habilidade de os microrganismos produzirem e secretarem exopolissacarídeos (EPS) (PRASAD et al., 2005).

Um dos problemas deste tipo de imobilização está relacionado com a formação e acúmulo de biofilme ou EPS sobre a superfície, o que dificulta a absorção de nutrientes resultante das condições não-homogêneas do 
crescimento celular. Os produtos secretados para o meio extracelular têm sua difusão dificultada e a troca gasosa também pode ser comprometida (XAVIER et al., 2003).

A produção de EPS por células microbianas imobilizadas em suportes porosos também tem sido descrita. Porém, como a secreção de EPS para o meio aumenta excessivamente a viscosidade do mesmo, o uso da imobilização celular é limitado para alguns tipos de microrganismos, de acordo com o comportamento reológico do meio de cultivo e o tipo de matriz utilizada (BERGMAIER; CHAMPAGNE; LACROIX, 2005).

O método de adsorção é utilizado pela sua simplicidade, baixo custo, fácil manipulação e grande diversidade de suportes. Há um potencial de equilíbrio entre as células adsorvidas e livres, dependendo do crescimento microbiano e da densidade de células na matriz. A equação 1 representa este equilíbrio entre as células livres $\left(C_{\text {livres }}\right)$ e adesão no suporte $(S)$ e as células enfim imobilizadas

$\left(C_{\text {imobilizadas }}\right)$. Pode observar-se na Figura 6 , que o ponto de equilíbrio ocorre no início da fase estacionária de adsorção das células (COVIZZI et al.; 2007).

$$
\mathrm{C}_{\text {livres }}+\mathrm{S} \leftrightarrow \mathrm{C}_{\text {imobilizadas }}
$$

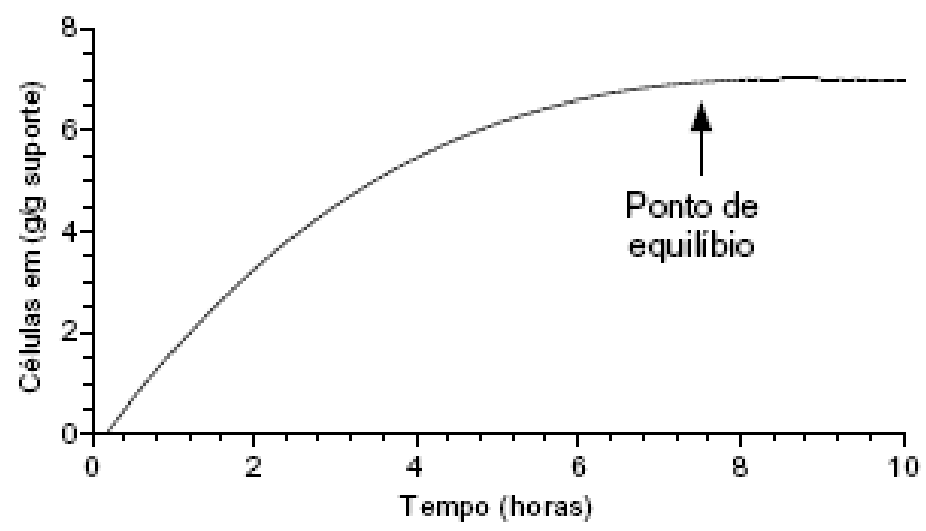

Figura 6 - Equilíbrio entre células livres e imobilizadas no suporte pelo princípio de adsorção (Fonte: COVIZZI et al.; 2007).

A grande vantagem da imobilização celular para a produção de enzimas é que este sistema permite a produção contínua e eficiente destas proteínas pelos microrganismos, por um longo período de tempo (DOMÍNGUEZ; COUTO; SANROMÁN, 2001). Quando se utilizam células livres, ocorre um pico de atividade enzimática e, no caso do uso de microrganismos imobilizados, ocorre um platô de atividade que pode durar por um período mais longo (PRASAD et al., 2005). O uso de esporos neste tipo de imobilização não é recomendável, uma vez que a agregação destes sobre a superfície do suporte é muito lenta e, em alguns casos, após o processo de imobilização, o fungo cresce na forma de "pellets" e fica disperso no meio de cultivo (GERIN; ASTHER; ROUXHET, 1997).

\subsection{Envolvimento de células microbianas em matrizes}

O método de envolvimento está baseado na inclusão artificial das células, que ficam inseridas em uma malha rígida, ou semi-rígida, que impede a difusão destas para o meio de cultivo. Este aprisionamento do microrganismo possibilita a troca de nutrientes, metabólitos, gases durante o processo fermentativo. A diferença entre este método e o de encapsulação é que, neste último, as células ficam apenas envoltas por uma membrana e não há uma malha entre as células por ela envolvidas. (CHAMPAGNE; LACROIX; SODINI-GALLOT, 1994; KRISHNAN et al., 2001).

O mecanismo clássico de imobilização por envolvimento é a mistura de células microbianas com um composto polimérico que apresenta cargas negativas (alginato, pectato, ou outro polímero orgânico com cargas negativas). Esta mistura é gotejada em uma solução com íons $\mathrm{Ca}^{2+}$, por exemplo, conforme ilustra a Figura 7. O 
íon $\mathrm{Ca}^{2+}$ promove a formação de ligações iônicas, que resultam na formação de um gel consistente e insolúvel, o qual imobiliza o microrganismo. O tamanho da barreira de contenção formada em torno das células irá depender da velocidade de fluxo, da densidade da solução polimérica e da concentração da solução iônica, na qual o gel será formado. No processo de encapsulação, as células microbianas são colocadas em uma solução de cloreto de cálcio, que é gotejada a posteriori na solução polimérica, na qual será formada a cápsula envoltória (WANG et al., 2005).

O crescimento celular nestes tipos de imobilização celular depende da limitação imposta pela porosidade do material e do acúmulo de biomassa no interior da matriz. São vários os géis utilizados como: agar, agarose, goma carragenana, alginato e quitosana, além de géis como o álcool polivinílico (PARASCANDOLA; BRANDUARDI; ALTERIIS, 2006).

A imobilização de células microbianas em géis de alginato tem sido a mais utilizada em processos fermentativos, envolvendo bactérias, leveduras, e mais raramente, fungos. Como exemplo, pode ser citada a produção de ácido lático por Lactobacillus casei (YOO et al., 1996) e de carotenóides pelo fungo filamentoso Giberella fujikuroi (GARBAYO et al., 2003).

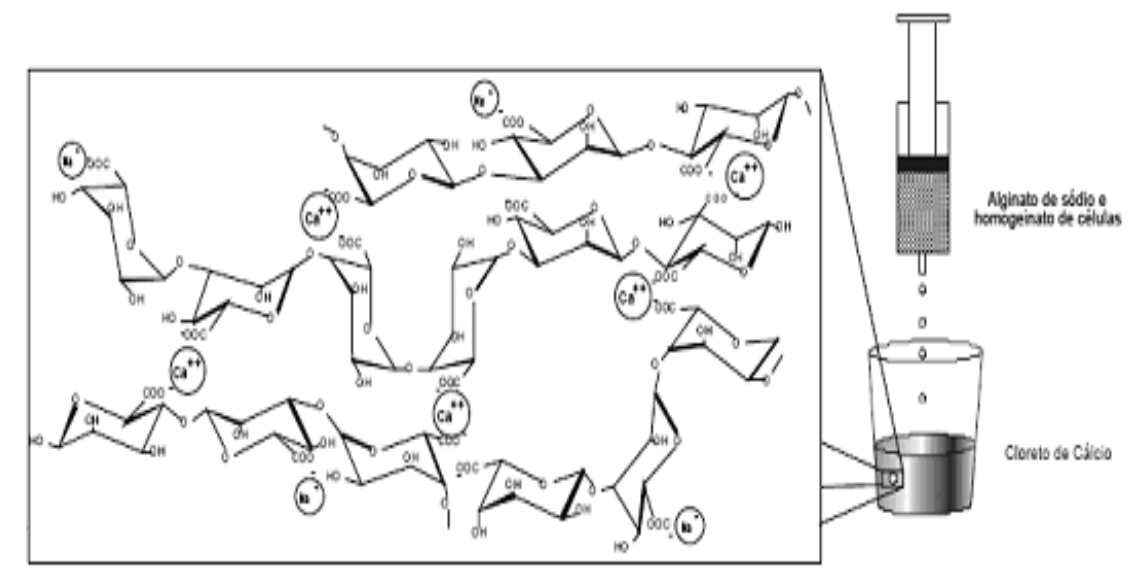

Figura 7 - Formação do gel de alginato de cálcio por envolvimento (Fonte: COVIZZI et al.; 2007).

O alginato é um polissacarídeo linear constituído por unidades de ácido manurônico ligado por ligações glicosídicas do tipo $\beta(1 \rightarrow 4)$, e também, por unidades de ácido gulurônico, unidas por ligações do tipo $\alpha(1 \rightarrow 4)$ (GUO et al., 2006). Seu uso apresenta vantagens como baixo custo, grande disponibilidade no mercado, possibilidade de ampliação de escala de produção e a aceitação das substâncias utilizadas para a imobilização.

\subsection{Biodiesel}

O biodiesel é uma denominação genérica para combustíveis e aditivos derivados de fontes renováveis, (CANAKCI e VAN GERPEN, 2001; MONYEM, 2001) e sua utilização está associada à substituição de combustíveis fósseis em motores do ciclo diesel (KNOTHE, 2002; HAAS et al., 2001), sem haver a necessidade de nenhuma modificação no motor (LUE, 2001). Isso porque o óleo diesel é composto por longas cadeias de hidrocarbonetos que variam de 12 a 22 carbonos. Alguns ésteres de óleo vegetal apresentam características muito próximas a do diesel (GOLDEMBERG, 2003).

O biodiesel é um composto biodegradável e renovável e constituído de uma mistura de ésteres metílicos ou etílicos de ácidos graxos e glicerol, obtidos da reação de transesterificação de qualquer triglicerídeo de óleos e gorduras de origem vegetal ou animal com um álcool de cadeia curta, metanol ou etanol (PARENTE, 2003; GERPEN, 2005), na presença de um catalisador.

O biodiesel tem todas as características para substituir o óleo diesel, com a vantagem de ser livre de enxofre e de compostos orgânicos, alto número de cetano; teor médio de oxigênio; maior ponto de fulgor; menor emissão de partículas, HC, CO (HAAS et al., 2001; PETERSON et al., 2002; FELIZARDO, 2003 e NABI et al., 
2006) e permite que se estabeleça um ciclo fechado de carbono no qual o $\mathrm{CO}_{2}$ liberado na combustão é reabsorvido no crescimento da massa vegetal (FERRARI, 2005). Seu caráter renovável está associado a sua matéria prima por ser oriunda de práticas agrícolas além de diminui as emissões de gases causadores do efeito estufa (HAAS et al., 2001; LUE et al., 2001). Bhale et al. (2009) estudaram o desempenho e emissões da mistura entre etanol, diesel fóssil e biodiesel obtido de "Madhuca indica", uma árvore comum em solo indiano. Avaliou-se a emissão para várias cargas aplicadas a um motor com rotação de $1500 \mathrm{rpm}$. A redução na emissão de CO foi mais de $50 \%$ para a blenda com $20 \%$ de etanol. Já para as emissões de hidrocarbonetos, o melhor resultado ocorreu para o biodiesel puro, reduzindo em média 12,4 \% em relação ao petrodiesel. Embora o biodiesel apresente maior emissão de NOx em relação ao diesel fóssil, a blenda com $20 \%$ de etanol apresentou menor emissão do que o petrodiesel. Já para a emissão de particulados (fumaça), todas as blendas apresentaram menores valores do que o petrodiesel, especialmente em altas cargas.

Apesar de todas as vantagens do biodiesel no Brasil, a produção deste biocombustível ainda é alta, pois o valor elevado do óleo virgem torna o biodiesel pouco competitivo em relação ao diesel fóssil. Isso porque uma das maiores dificuldades para sua implementação é o preço do óleo diesel mineral, que apresenta um valor muito baixo em relação aos outros derivados do petróleo. Uma alternativa viável seria iniciativas de fabricação a partir de óleos usados e gorduras animais são alternativas para a redução do custo (DUBÉ et al., 2007).

A motivação para o desenvolvimento de programas de produção de bioenergia está ligada aos aspectos ambientais, com o propósito de redução de gases geradores do efeito estufa, bem como minimizar dependências de importações de petróleo, além de contribuir ainda, para o desenvolvimento sustentável e uso racional de recursos renováveis (PITT, 2010).

\subsection{Processo de produção do biodiesel}

O processamento da matéria prima para sua conversão em biodiesel visa criar melhores condições para a efetivação da reação química, obtendo-se máxima taxa de conversão. No caso da biomassa rica em óleo vegetal o primeiro passo é a obtenção do óleo que pode ser feita por meio de extração mecânica (esmagamento), extração com solvente e/ou extração mista (JORDÃO FILHO, 2004).

O processo mais empregado para produção de biodiesel é a transesterificação, que consiste na reação de um triglicerídeo com um álcool de cadeia curta, na presença de um catalisador. Como resultado, obtém-se ésteres de ácidos graxos metílicos ou etílicos (biodiesel) e glicerina (PINTO et al., 2005). O fluxograma mostra o processo de produção do biodiesel a partir de óleos e gorduras ricas em triglicerídeos, principal matéria-prima para obtenção deste biocombustível, como pode ser visto na Figura 8. 


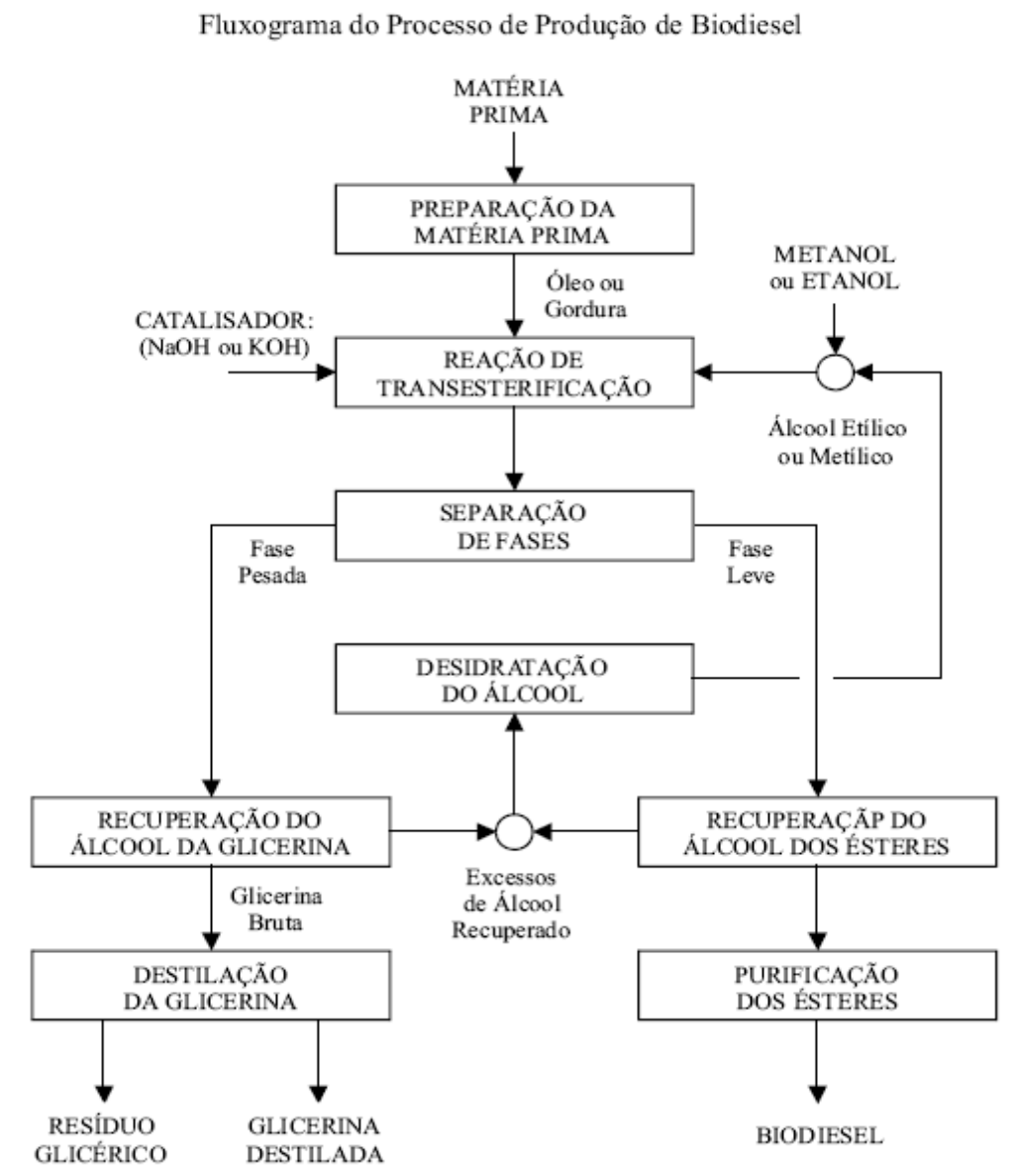

Figura 8 - Processo de produção de biodiesel. Fonte: PARENTE, 2003.

\subsubsection{Preparação da matéria-prima}

A matéria-prima deve ser submetida a um processo de neutralização, por meio de lavagem com solução alcalina de hidróxido de potássio ou sódio, seguido de uma operação de secagem e desumidificação, isso para que a matéria prima tenha o mínimo possível de umidade e acidez. As especificidades do tratamento dependem da natureza e das condições da matéria-prima empregada (DORADO, 2004).

\subsubsection{Transesterificação}

A reação de transesterificação de um triglicerídeo com metanol deve ser realizada com um excesso de álcool para forçar o equilíbrio para sentido do produto desejado. Apesar de o metanol ser o mais freqüentemente utilizado, por razões de natureza física e química (cadeia curta e polaridade), o etanol se torna mais interessante por ser produzido em larga escala no Brasil, além de ser renovável e muito menos tóxico. Para acelerar a reação um catalisador é normalmente usado, podendo este ser básico, ácido ou enzimático (HOLANDA, 2004). O hidróxido de sódio é o catalisador mais usado tanto por razões econômicas como pela sua disponibilidade no mercado (PARENTE, 2003). Porém estudos revelam que o uso de lipases, como catalisador biológico, para a hidrólise de gorduras em âmbito industrial proporciona vantagens como a diminuição de gastos com energia e a minimização da degradação térmica dos compostos, quando comparados às vias químicas tradicionais. Estas são 
provavelmente as principais atrações que levam à substituição das tecnologias químicas atuais pelas biológicas (HASAN et al.,2006, ROYON et al., 2007).

\subsubsection{Separação de Fases}

O produto da reação de transesterificação gera uma massa reacional final, que é constituída por duas fases, que podem ser separadas por decantação ou centrifugação. A fase mais pesada dessa massa é composta por glicerina bruta e a fase menos densa é constituída por uma mistura de ésteres etílicos e metílicos. (PARENTE; 2003). Esta separação é uma etapa importante da produção de biodiesel, pois o processo de refino dos produtos decorrentes da sua produção pode ser tecnicamente difícil e pode elevar os custos de produção. Além disso, a pureza do biodiesel precisa ser alta (DORADO, 2004), e de acordo com a especificação da União Européia, o teor de ácidos graxos livres, álcool, glicerina e água devem ser mínimos de modo que a pureza do biodiesel seja maior que 96,5\% (MA e HANNA, 1999).

A mistura típica do produto de uma reação de transesterificação contém ésteres, monoglicerídeos, diglicerídeos, glicerol, álcool e catalisador, em várias concentrações. Na separação, o principal objetivo é remover os ésteres dessa mistura, a baixo custo, e assegurar um produto de alta pureza. $\mathrm{O}$ glicerol na sua forma pura é visto como um produto secundário da reação, mas, para manter a competitividade do custo de produção, a remoção e a revenda de glicerol é essencial (MA e HANNA, 1999).

Além da glicerina, a cadeia produtiva do biodiesel gera uma série de outros co-produtos (tortas, farelos, entre outros) que podem agregar valores e se constituírem em outras fontes de renda importantes para os produtores.

\subsubsection{Recuperação e desidratação do álcool}

A fase pesada contém água e álcool e deve ser submetida a um processo de evaporação. Os vapores de água e álcool são, a seguir, liquefeitos em um condensador. Da mesma forma, o álcool residual é recuperado da fase leve liberando os ésteres metílicos ou etílicos para as etapas seguintes. Após essa recuperação, o álcool ainda contém água e deve ser desidratado. Essa desidratação é normalmente feita por destilação (SCHUCHARDT, 1998).

\subsubsection{Destilação da glicerina}

O glicerol é o principal subproduto gerado na produção de biodiesel, sendo que aproximadamente $10 \%$ do volume total de biodiesel produzido correspondem a glicerol (DASARI et al., 2005). Devido a isso, torna-se necessário a busca de alternativas para o uso do glicerol bruto gerado nesta produção, com o intuito de evitar futuros problemas derivados do acúmulo de glicerol e para tornar a produção de biodiesel mais competitiva, (OOI et al.,2004).

A glicerina bruta, emergente do processo, mesmo com suas impurezas convencionais, já constitui o subproduto rentável. No entanto a glicerina pode ser purificada e desta forma lhe ser agregado um valor de mercado muito mais favorável. A purificação da glicerina bruta pode ser feita por destilação a vácuo, gerando um produto límpido e transparente. O produto de calda da destilação, ajustável na faixa de $10 \%$ a $15 \%$ do peso da glicerina bruta, pode ser denominado de "glicerina residual" e ainda encontra possíveis aplicações (YONG et al., 2001).

A conversão microbiana de glicerol por processos biotecnológicos em produtos de maior valor agregado, como biomassa e biomoléculas, é uma alternativa relevante para a maior valorização da produção de biodiesel. Sendo assim, estratégias mais detalhadas para a utilização biotecnológica do glicerol são esperadas em poucos anos, de forma a reduzir os impactos ambientais e tornar o biodiesel um produto altamente competitivo no mercado mundial de biocombustíveis (ITO et al., 2005). 


\subsubsection{Purificação do biodiesel}

Caso a reação de transesterificação seja incompleta ou caso a purificação seja insuficiente, o biodiesel produzido pode ficar contaminado com glicerol, triglicerídeos e álcool. A presença de contaminantes pode ser prejudicial para os motores e para o meio ambiente. Os ésteres deverão ser lavados por centrifugação e, posteriormente, desumidificados, resultando finalmente no biodiesel, o qual deverá ter suas características enquadradas nas especificações das normas técnicas estabelecidas para o biodiesel como combustível para uso em motores do ciclo diesel. (SCHUCHARDT, 1998).

Nos últimos anos têm sido feitos vários estudos para o desenvolvimento de métodos para análise do biodiesel, suas impurezas e subprodutos. Esses estudos incluem a cromatografia gasosa, a separação da fase sólida, a cromatografia de filme líquido, a cromatografia líquida de alta precisão, a refractometria, entre outras. As técnicas de análise devem ser precisas, confiáveis, reprodutíveis, rápidas e simples, e requerer equipamentos disponíveis. A cromatografia gasosa tem sido o método mais aceito para análise do biodiesel, devido a sua simplicidade e pelo alto nível de precisão.

Cromatografia Gasosa é uma técnica para separação e análise de misturas de substâncias voláteis. A amostra é vaporizada e introduzida em um fluxo de um gás adequado denominado de fase móvel ou gás de arraste. Este fluxo de gás com a amostra vaporizada passa por um tubo contendo a fase estacionária (coluna cromatográfica), onde ocorre a separação da mistura. A fase estacionária pode ser um sólido adsorvente (Cromatografia Gás-Sólido) ou, mais comumente, um filme de um líquido pouco volátil, suportado sobre um sólido inerte (Cromatografia Gás-Líquido com Coluna Empacotada ou Recheada) ou sobre a própria parede do tubo (Cromatografia Gasosa de Alta Resolução) (COLLINS e AQUINO).

As substâncias separadas saem dissolvidas da coluna no gás de arraste e passam por um detector; dispositivo que gera um sinal elétrico proporcional à quantidade de material eluído. $\mathrm{O}$ registro deste sinal em função do tempo é o cromatograma, sendo que as substâncias aparecem nele como picos com área proporcional à sua massa, o que possibilita a análise quantitativa (FOGLIA et al., 2004).

Entre esses métodos, a cromatografia de fase gasosa pode ser considerada uma ferramenta muito eficaz na determinação da composição do biodiesel em termos de ésteres de ácidos graxos, mesmo para amostras contendo baixos teores. A escolha do detector é muito importante, pois é ele que indica e quantifica os componentes separados pela coluna. Os dois detectores mais utilizados em cromatografia gasosa são os Detectores por Condutividade Térmica (DCT) e o por Ionização em Chama (DIC ou FID) (FOGLIA et al., 2005).A cromatografia de gás é uma das ferramentas mais importantes na química. Isso devido a sua simplicidade, sensibilidade e efetividade para separar os componentes de misturas.

\section{CONSIDERAÇÕES FINAIS}

A utilização de biodiesel como combustível vem sendo estudada por apresentar um potencial promissor no mundo, sendo um mercado que cresce devido, a sua contribuição ao meio ambiente, com a redução qualitativa e quantitativa dos níveis de poluição ambiental, principalmente nos grandes centros urbanos, e como fonte de energia renovável em substituição ao óleo diesel e outros derivados do petróleo.

A demanda pelo desenvolvimento de tecnologias que diminuem os gastos dos processos industriais, vem ganhando cada vez mais espaço no mercado, e dentre estas, o biocatalisador é uma alternativa tanto na redução de impacto ambiental, quanto na minimização dos resíduos gerados no processo. Sendo assim, novas técnicas de imobilização celular vêm sendo investigada para otimização do processo de produção do biodiesel. O grande interesse por estas tecnologias está relacionado com a produção de suportes como matrizes para a imobilização de células, pois estas minimizam os efeitos causados pelo seu uso em ambientes adversos, tais como solventes orgânicos, variações no $\mathrm{pH}$ e altas temperaturas, de maneira que seja preservada a atividade catalítica desejada, para aplicação tanto em escala laboratorial quanto industrial. 


\section{REFERÊNCIAS BIBLIOGRÁFICAS}

ALMEIDA, J. A. N.; NASCIMENTO, J. C.; SAMPAIO, L.A. G., CHIAPETTI, J., GRAMACHO R. S., C., N. S. E ROCHA,V. A., (2007). Projeto Bio- Combustível: processamento de óleos e gorduras vegetais in natura e residuais em combustível tipo diesel, Universidade Estadual de Santa Cruz- UESC, Ilhéus-BA[online]. Disponível em: $<$ http://www.uesc.br/ecodiesel/trab_completos/Agrenercompleto2000.pdf $>$. [capturado em 15 de outubro de 2008].

AQUINO NETO, F. R.; NUNES, D. S. S. Cromatografia- Princípios Básicos e técnicas afins. Rio de Janeiro: Editora Interciência, 2003, 187p.

BHALE, P. V.; DESHPANDE, N. V.; THOMBRE, S. B.; Improving the low temperature properties of biodiesel fuel, Renewable Energy. v. 34, p. 794-800, 2009.

BERGMAIER, D.; CHAMPAGNE, C. P.; LACROIX, C. Growth and exopolysaccharide production during free and immobilized cell chemostat culture of Lactobacillus rhamnosus RW-9595M. Journal of Applied Microbiology, Oxford, v. 98, n. 2, p. 272-284, 2005.

CANAKCI, M.; VAN GERPEN, J. Biodiesel production from oils and fats with high free fatty acids. Transactions of the ASABE, v. 44, p. 1429-1436, 2001.

CHAMPAGNE, C. P.; LACROIX, C.; SODINI-GALLOT, I. Immobilized cell technologies for the dairy industry. Critical Reviews in Biotechnology, Boca Raton, v. 14, n. 2, p. 109-134, 1994.

COLLINS, C.; BRAGA, G. L.; BONATO, P. S. Introdução a Métodos Cromatográficos. Campinas: Editora da UNICAMP, 1997. 229p.

CONCEIÇÃO, M. M.; CANDEIA, R. A.; DANTAS, H. J.; SOLEDADE, L. E. B.; FERNANDES Jr, V. J.; SOUZA, A. G.; Rheological Behavior of Castor Oil Biodiesel. Energy \& Fuel, v. 19, p. 2185-2188, 2005.

COSTA, N. P. R.; ROSSI, L.F.S. Produção de biocombustível alternativo ao óleo diesel através da transesterificação de óleo de soja usado em frituras. In: Revista Química Nova, Curitiba - PR, v. 23, n. 4, p.531537,2000 .

COSTA NETO, P. R. Obtenção de lipídeos estruturados por interesterificação de triacilgliceróis de cadeia média e longa. 2001, 185p. Tese (Doutorado em Tecnologia Bioquímico-Farmacêutica). Universidade de São Paulo. São Paulo.

COVIZZI, L. G., GIESE, E. C., GOMES, E., DEKKER, R. F. H., SILVA, R., Imobilização de células microbianas e suas aplicações biotecnológicas. Revista Ciências Exatas e Tecnológicas, Londrina, v. 28, n.2, p. 143-160, jul./dez. 2007.

DALLA-VECCHIA, R., NASCIMENTO, M. G., SOLDI, V. Aplicações Sintéticas de Lipases Imobilizadas em Polímeros. Revista Química Nova, v. 27, N. 4, p. 623-630, 2004.

DASARI, M. A.; KIATSIMKUL, P. P.; SUTTERLIN, W. R.; SUPPES, G.J.; Low-pressure hydrogenolysis of glycerol to propylene glycol, Applied Catalysis A: General, v. 281, p. 225-231, 2005. 
De CASTRO, H. F.; MENDES, A. A.; SANTOS, J. C.; AGUIAR, C.L. Modificação de óleos e gorduras por biotransformação. Revista Química Nova, v. 27, n. 1, p. 146-156, 2004.

DOMÍNGUEZ, A.; COUTO, S. R.; SANROMÁN, A. Amelioration of ligninolytic enzyme production by Phanerochaete chrysosporium in airlift bioreactors. Biotechnology Letters, Dordrecht, v. 23, n. 6, p. 451-455, 2001.

DORADO, M. P., OPTIMIZATION of Alkali-Catalyzed Transesterification of Brassica Carinata Oil for Biodiesel Production, Energy \& Fuels, v.18, p. 77-83, 2004.

DUBÉ, M. A.; TREMBLAY, A. Y.; LIU, J.; Biodiesel production using a membrane reactor, Bioresource Technology v. 98, p. 639-647, 2007.

FACULDADE DE CIÊNCIAS MÉDICAS, Potencialidade da Produção de Biodiesel utilizando Óleos Vegetais e Gorduras Residuais, 2005. Disponível em: $<$ http://www.rbb.ba.gov.br/arquivo/132.pdf $>$. [capturado em $24 \mathrm{de}$ novembro 2008].

FELIZARDO, P. M. G. Produção de biodiesel a partir de óleos usados de frituras- Lisboa: Centro de informação de Resíduos, Instituto Superior Técnico, Departamento de Engenharia Química, 127p. Relatório Técnico, 2003.

FENG, K. C.; ROU, T. M.; LIU, B. L.; TZENG, Y. M.; CHANG, Y. N. Effect of fungal pellet size on the high yield production of destruxin B by Metarhizium anisopliae. Enzyme and Microbial Technology, New York, v. 34 , n. 1, p. 22-25, 2003.

FERRARI, R. A.; OLIVEIRA, V. D.; OSCABIO, A. Biodieselk de soja-Texa de conversão em ésteres etílicos, caracterização físico-química e consumo em gerador de energia. Revista Química Nova. V.28, n.1, p.19-23, 2005 .

FIELD'S K. A. P.; DAMASCENO K. H. R.; MARTINS, M. M.; JUNIOR, D. O. A.; CORDEIRO, D. L. Aquisição de conhecimento por meio da produção de biodiesel por craqueamento. XIV encontro Nacional de ensino de Química. Cód. 539-2. São Paulo, 2008.

FOGLIA, T. A.; JONES, K. C.; PHILLIPS, J. G. Determination of biodiesel and triacylglycerol in diesel fuel by high performance liquid chromatography. Chromatographia. v.62, p.115-119, 2005.

FOGLIA, T. A.; JONES, K. C.; NUNEZ, A.; PHILLIPS, J. G.; MITTELBACH, M. Comparison of chromatographic methods for the determination of bound glycerol in biodiesel. Chromatographia. v. 60, p. 305$311,2004$.

FREEMAN, A.; LILLY, M. D. Effect of processing parameters on the feasibility and operational stability of immobilized viable microbial cells. Enzyme and Microbial Technology, New York, v. 23, n. 5, p. 335-345, 1998.

GARBAYO, I.; VILCHEZ, C.; NAVA-SAUCEDO, J. E.; BARBOTIN, J. N. Nitrogen, carbon and lightmediated regulation studies of carotenoid biosynthesis in immobilized mycelia of Gibberella fujikuroi. Enzyme and Microbial Technology, New York, v. 33, n. 5, p. 629-634, 2003.

GERIN, P. A.; ASTHER, M.; ROUXHET, P. G. Peroxidase production by the filamentous fungus Phanerochaete chrysosporium in relation to immobilization in "filtering" carriers. Enzyme and Microbial Technology, New York, v. 20, n. 4, p. 294-300, 1997. 
GERIS, R.; SANTOS, N. A. C.; AMARAL, B. A.; MAIA, I. S.; CASTRO, V. D.; CARVALHO, J. R. M. Biodiesel de soja - Reação de transesterificação para aulas práticas de química. Química Nova, v. 30, n. 5, p. 1369-1373, 2007.

GERPEN, J. V. Biodiesel processing and production. Fuel Processing Technology. v. 86, p. 1097-107, 2005.

GUO, X-L.; DENG, G.; XU, J.; WANG, M-X. Immobilization of Rhodococcus sp. AJ270 in alginate capsules and its application in enantioselective biotransformation of trans-2-methyl-3-phenyl-oxiranecarbonitrile and amide. Enzyme and Microbial Technology, New York, v. 39, n. 1, p. 1-5, 2006.

HA, S.H., LAN, M.N., LEE, S.H., HWANG, S.M., KOO, Y. M. Lipase-catalyzed biodiesel production from soybean oil in ionic liquids. Enzyme and Microbial Technology. V. 41, p. 480-483, 2007.

HAAS, M. J.; SCOTT, K. M.; ALLEMAN, T. L.; MCCORMICK, R. L.; Engine performance of biodiesel fuel prepared from soybean soap stock: A high quality renewable fuel produced from a waste feedstock. Energy Fuels, v. 15, p. 1207, 2001.

HASAN, F., SHAH, A.A., HAMEED, A. Industrial applications of microbial lipases. Enzyme and Microbial Technology. v. 39, p. 235-251, 2006.

HE, Q.; XU, Y., TENG, Y., WANG, D. Biodiesel Production catalyzed by whole cell lipase from Rhizopus chinesis Chin. Journal of Catalysis. v. 29, p. 41-46, 2008.

HOLANDA, A. Biodiesel e Inclusão Social. Brasília: Câmara dos Deputados, Coordenação de Publicações, Série cadernos de altos estudos. 200 p., n. 1, 2004.

ITO, T.; NAKASHIMADA, Y.; SENBA, K.; MATSUI, T.; NISHIO, M. ; J. Hydrogen and ethanol production from glycerol-containing wastes discharged after biodiesel manufacturing process. Journal of Bioscience and Bioengineering, v. 100, p. 260-265, 2005.

JAEGER, K. E.; EGGERT, T. Lipase for Biotechnology. Current Opinion in Biotechnology, v. 13, p. 390-397, 2002 .

JORDÃO FILHO, W. Implementação de negócios de biodiesel no Brasil: Estudo de viabilidade técnica e financeira preliminar, 2004.

JUNTER, G. A.; JOUENNE, T. Immobilized viable microbial cells: from the process to the proteome in leader or the cart before the horse. Biotechnology Advances, New York, v. 22, n. 8, p. 633-658, 2004.

KNOTHE, G. Struture indices in FA chemistry. How relevant is the iodine value? Journal of the American Oil Chemists' Society, v.79, p. 847-854, 2002

KNOTHE, G. Dependence of biodiesel fuel properties on the structure of fatty acid alkyl esters. Fuel Processing Technology, v. 86, p. 1059-1070, 2005.

KOURKOUTAS, Y.; MCERLEAN, C.; KANELLAKI, M.; HACK, C. J.; MARCHANT, R.; BANAT, I. M.; KOUTINAS, A. A. High-temperature wine making using the thermotolerant yeast strain Kluyveromyces marxianus IMB3. Applied Biochemistry and Biotechnology, Clifton, v. 112, n. 1, p. 25-35, 2004. 
KRISHNAN, A. S.; LALITHA, R. G. A.; MISRA, A. M. C.; KARANTH, N. G. Physiological and morphological changes in immobilized L. Plantarum ncim 2084 cells during repeated batch fermentation for production of lactic acid. Food Biotechnology, New York, v. 15, n. 3, p. 193-202, 2001.

LEE, K. T.; FOGLIA, T. A.; CHANG K. S. Product ion of A lkyl Est e $\mathrm{r}$ as B iodiese $1 \mathrm{f}$ rom Fract ionated Lard and Restaurant Grease. Journal of the Amer ican Oil Chemists' Society, V. 7 9, n. 2, p. 191 - 195, 2002.

LUE, Y. F.; YEH, Y. Y.; WU, C. H. The emission characteristics of a small DI diesel engine using biodiesel blended fuels. Journal of Environmental Science \& Health, Part A: Environmental Science \& Engineering, v. 36 , p. 845-859, 2001.

MA, F.; HANNA, M. A. biodiesel production: a review. Bioresorce Technology, v. 70,p 1-15, 1999.

MARCHETTI, J. M.; MIGUEL, V. U.; ERRAZU, A. F. Pooible methods for biodiesel production. Renewable \& Sustainable Energy Reviews. v. 11, p. 731-736, 2005.

MEHER, L.C.;SAGAR, D. V.; NAIK, S. N. Technical aspects of biodiesel production by transesterification- A review. Renewable \& Sustainable Energy Reviews, v. 10, p. 248-268, 2006.

MELO, J. C.; PACHECO, J. G. A.; STRAGEVITCH, L.; BARBOSA, F. L. P.; JUCÁ, J. F. T.; NEVES, A. M.; Cinética da Transesterificação do Óleo de Algodão para a Produção de Biodiesel[online]. Disponível em: $<$ http://www.biodiesel.gov.br/docs/congresso2007/producao/15.pdf $>$. [capturado em 18 maio 2011]

MILINSK, M. C. Análise comparativa entre oito métodos de esterificação na determinação quantitativa de ácidos graxos em óleo vegetal. 2007. Tese (Doutorado) Universidade Estadual de Maringá. Centro de Ciências Exatas Departamento de Química, Maringá.

MINISTÉRIO DA CIÊNCIA E TECNOLOGIA, Programa brasileiro de biocombustíveis: rede brasileira de biodiesel - PROBIODIESEL. Brasília, 2002.

MITTELBACH, M.; POKITS, B.; SILBERHOLZ, A. Production and Fuel Properties of Fatty Acid Methyl Esters from Used Frying Oil. Institute of organic chemistry, Karl-Franzens Universitat Graz, Heinrichstrabe, v. 28, A-8010 Graz, Austria, 1988.

MONYEM, A.; VAN GERPEN, J. H.; CANAKCI, M. The effect of timing and oxidation emissions from biodiesel-fueled engines. Transactions of the ASABE, v. 44, p. 35-42, 2001.

MOREIRA, M. T.; PALMA, C.; FEIJOO, O.; LEMA, J. M. Strategies for the continuous production of ligninolytic enzymes in fixed and fluidised bed bioreactors. Journal of Biotechnology, Amsterdam, v. 1, n. 66, p. 27-39, 1998.

NABI, MD. NURUN, AKHTER, MD. SHAMIM \& SHAHADAT, MHIA MD. ZAGLUL. Improvement of engine emissions with convencional diesel fuel and diesel-biodiesel blends. Bioresource Technology, v. 97, p.372-378, 2006.

NASCIMENTO, M. G.; COSTA NETO, P. R.; MAZZUCO, L. M. Biotransformação de óleos e gorduras. Biotecnologia Ciência e Desenvolvimento, v 17, p. 28-31, 2001. 
OLIVEIRA, L.B.; MUYLAERT , M.S., ; ROSA, L. P.; BARATA, M.; ROVERE, E. Analysis of the sustainability of using wastes in the Brazilian power industry. Renewable and Sustainable Energy Reviews. v. 12, p. 883-890, 2006.

OOI, T. L.; YONG, K. C.; HAZIMAH, A. H.; DZULKEFLY, K.; WAN-YUNUS, W. M. Z.; Glycerol Residue - A Rich Source of Glycerol and Medium Chain Fatty Acids. Journal of Oleo Science. v. 53, p. 29-33, 2004.

PARASCANDOLA, P.; BRANDUARDI, P.; ALTERIIS, E. d. PVA-gel (Lentikats®) as an effective matrix for yeast strain immobilization aimed at heterologous protein production. Enzyme and Microbial Technology, New York, v. 38, n. 5, p. 184-189, 2006.

PARENTE JR, E.; CASTELO BRANCO, P. T. Análise Comparativa entre etanol e metanol visando sua utilização como coadjuvante químico na produção do biodiesel. Organizado pela Coordenação de Publicações, Série Cadernos de Altos estudos Biodiesel e Inclusão Social, Brasília, Câmara dos Deputados, 2004, p. 83-88.

PARENTE,E. J. S. Biodiesel: uma aventura tecnológica num país engraçado, Fortaleza, 2004.

PETERSON, C. L.; COOK, J. L.; THOMPSON, J. C.; TABERSKI, J. S. Continuous flow biodiesel production. Appl. Engenharia da Agricultura. n. 18, p. 5-11, 2002.

PETRE, M.; ZARNEA, G.; ADRIAN, P.; GHEORGHIU, E. Biodegradation and bioconversion of cellulose wastes using bacterial and fungal cells immobilized in radiopolymerized hydrogels. Resources, Conservation and Recycling, Amsterdam, v. 27, n. 4, p. 309-332, 1999.

PILKINGTON, P. H.; MARGARITIS, A.; MENSOUR, N. A.; RUSSEL, I. Fundamentals of immobilized yeast cells for continuous beer fermentation: A review. Journal of the Institute of Brewing, London, v. 104, p. 19-31, 1998.

PINTO, A. C.; GUARIEIRO, L. L. N.; REZENDE, M. J. C.; RIBEIRO, N. M.; TORRES, E. A.; LOPES, W. A.; PEREIRA, P. A. P.; DE ANDRADE, J. B.; Jounal Brazilian Chemistry. Socirity. v. 16, p. 1313, 2005.

PITT, F. D. Desenvolvimento de Metodologia para Polimerização do Poliglicerol Adípico a partir do Glicerol Residual Oriundo da Produção de Biodiesel. 2010. Tese (mestrado). Universidade Regional de Blumenau, Centro de Ciências Tecnológicas, Blumenau.

PRASAD, K. K.; MOHAN, S. V.; BHASKAR, Y. V.; RAMANAIAH, S. V.; BABU, V. L.; PATI, B. R.; SARMA, P. N. Laccase production using Pleurotus ostreatus 1804 immobilized on PUF cubes in batch and packed bed reactors: influence of culture conditions. Journal of Clinical Microbiology, Washington, v. 43, n. 3, p. 301-307, 2005.

RAMOS, L. P. et al. Biodiesel: Um projeto de sustentabilidade econômica e sócio-ambiental para o Brasil. Revista Biotecnologia Ciência e desenvolvimento, v. 31, p. 28-37, 2003.

RINALDI, R.; GARCIA, C.; MARCINIUK, L. L.; ROSSI, A. V.; SCHUCHARDT, U. Síntese de biodiesel: Uma proposta contextualizada de experimento para laboratório de química geral. Química Nova, v. 30, n. 5, p. 1374-1380, 2007. 
ROYON, D., DAZ, M., ELLENRIEDER, G., LOCATELLI, S. Enzymatic production of biodiesel from cotton seed oil using t-butanol as a solvent. Bioresource Technology. v. 98, p. 648-653, 2007.

SCHUCHARDT, U., SERCHELI, R., VARGAS, R. M., "Transesterification of vegetable oils: a Review", Journal of Brazilian Chemistry Society, v. 9, nº 1, 1998.

SHINTANI, H. C.; YASUDA, F. Estudo da utilização do biodiesel em gerador de vapor na agroindústria. 2006. 106f. Monografia (Graduação em Engenharia Mecânica) - USP, São Paulo.

SILVA, A. J.; HIRASAWA, J. S.; VARESCHE, M. B.; FORESTI, E.; ZAIAT, M. Evaluation of support materials for the immobilization of sulfate-reducing bacteria and methanogenic archaea. Anaerobe, London, $\mathrm{v}$. 12, n. 2, p. 93-98, 2006.

SILVA, G. DE S.; MOURA, M. P.; MIRANDA, A. J. E MENEZES C. A. III Workshop Brasil-Japão em Energia, Meio-Ambiente e Desenvolvimento Sustentável 23 e 24 de Novembro de 2005 - UNICAMP Universidade Estadual de Campinas.

SOARES, V. C. D; LIMA, D. G. De; RIBEIRO, E. B.; CARVALHO, D. A.; CARDOSO, E. C. V.; RASSI, F. A.; MUNDIM, K. C.; RUBIM, J. C.; SUAREZ, P. A. Z. Diesel-like fuel obtained by pyrolysis of vegetable oils. Journal of Analytical and applaied pyrolysis, v. 71, n. 2, p. 987-996, 2004.

SOLOMONS, G.; FRYHLE, C. (7a Ed). Química Orgânica - v. 2. Rio de Janeiro-RJ: Editora LCT, 2002.

SUARES, P. A. Z.; MENEGHETTI, S. M. P. 70 aniversário do biodiesel em 2007: evolução histórica e situação atual no Brasil. Revista Química Nova. v. 30, p. 2068-2071, 2007.

SUAREZ, P. A. Z.; RUBIM, J. C.; MUNDIM, K. C. Sistemas de conversão de óleos vegetais, óleos usados e gorduras animais em combustíveis. UnB/Embrapa Patente: PI BR 0204019-0, 2002.

TISCHER, W.; KASCHE, V.; "Immobilized enzymes: crystal or carriers?", Trends in Biotechnology, v. 17, p. 326-335, 1999.

TURATTI , JANE M.; GOMES, RENATO A. R.; ATHIÉ , I. Lipídeos - Aspectos Funcionais e Novas Tendências, Instituto de Tecnologia de Alimentos: Campinas. p. 9-14, 58-61, 64-65, 2002.

VILLLENEUVE, P. et al. Customizing lipases for biocatalysis: A survey of chemical, physical and molecular biological approaches. Journal of Moolecular Catalysis B: Enzymatic, v. 9 n. 4-6, p. 113-148, 2000.

XAVIER, J. B.; PICIOREANU, C.; ALMEIDA, J. S.; LOOSDRECHT, M. C. M. V. Monitorização e modelação da estrutura de biofilme. Boletim de Biotecnologia, São Paulo, v. 76, n. 1, p. 2-13. 2003.

WANG, L.; RIDGWAY, D.; GU, T.; MOO-YOUNG, M. Bioprocessing strategies to improve heterologous protein production in filamentous fungal fermentations. Biotechnology Advances, New York, v. 23, n. 2, p. 115129, 2005.

WANG, Y., WU, H., ZONG, M.H. Improvement of biodiesel production by lipozyme TL IM-catalyzed methanolysis using response surface methodology and acyl migration enhancer. Bioresource Technology. V. 99, p. 7232-7237, 2008. 
YOO, I. K.; SEONG, G. H.; CHANG, H. N.; PARK, J. K. Encapsulation of Lactobacillus casei cells in liquidcore alginate capsules for lactic acid production. Enzyme and Microbial Technology, New York, v. 19, n. 5, p. 428-433, 1996.

YONG, K. C.; OOI, T. L; DZULKEFLY, K.; WAN-YUNUS, W. M. Z.; HAZIMAH, A. H. Refining of crude glycerol recovered from glycerol residue by simple vacuum distillation. Journal Oil Palm Research, v. 13, p. 3944, 2001. 